\title{
The characteristics of the HIV-1 Env glycoprotein contribute to viral pathogenesis
}

\author{
Silvia Pérez-Yanes ${ }^{1}$, Maria Pernas ${ }^{2, \#, ~ S i l v i a ~ M a r f i l, \#, ~ R o m i n a ~ C a b r e r a-~}$ \\ Rodríguez ${ }^{1}$, Raquel Ortiz ${ }^{3}$, Carla Rovirosa ${ }^{3}$, Judith Estévez-Herrera ${ }^{1}$, Isabel \\ Olivares $^{2}$, Concepción Casado ${ }^{2, *}$, Cecilio Lopez-Galindez ${ }^{2, *}$, Julià Blanco ${ }^{3,4, *}$ \\ and Agustin Valenzuela-Fernández ${ }^{1, *}$
}

${ }^{1}$ Laboratorio de Inmunología Celular y Viral, Unidad de Farmacología, Sección de Medicina, Facultad de Ciencias de la Salud de la Universidad de La Laguna (ULL), Campus de Ofra s/n, 38071 Tenerife, Spain.

(sperezya@ull.edu.es), (rcabrerr@ull.edu.es), (jesteveh@ull.edu.es),

(avalenzu@ull.edu.es)

${ }^{2}$ Unidad de Virologia Molecular, Laboratorio de Referencia e Investigación en Retrovirus. Centro Nacional de Microbiologia. Instituto de Salud Carlos III. Majadahonda 28220 Madrid. Spain.

(ccasado@isciii.es), (mpernas@isciii.es), (iolivar@isciii.es),

(ceciliolopezgalindez1462@gmail.com)

${ }^{3}$ Institut de Recerca de la Sida IrsiCaixa, Institut d'Investigació en Ciències de la Salut Germans Trias i Pujol (IGTP), 08916 Badalona, Spain.

${ }^{4}$ Universitat de Vic, Universitat Central de Catalunya, UVIC-UCC, 08500 Vic, Spain.

(smarfil@irsicaixa.es), (rortiz@irsicaixa.es), (crovirosa@irsicaixa.es),

(jblanco@irsicaixa.es)

"These authors contributed equally.

${ }^{*}$ Corresponding authors.

E-mail address for correspondece: avalenzu@ull.edu.es 


\section{Abstract}

2 The understanding of HIV-1 pathogenesis and clinical progression is incomplete

3 because of the variable contribution of host, immune and viral factors. The

4 involvement of viral factors has been investigated in extreme clinical phenotypes

5 from rapid progressors to long-term non-progressors (LTNPs). Among HIV-1

6 proteins, the envelope glycoprotein complex (Env) has concentrated many

7 studies for its important role in the immune response and in the first steps of viral

8 replication. In this study, we analyzed the contribution of 41 Envs from 24 patients

9 with different clinical progression rates and viral loads (VLs), LTNP-Elite

10 Controllers (LTNP-ECs); Viremic LTNPs (vLTNPs), and non-controller's

11 individuals contemporary to LTNPs or recent, named Old and Modern

12 progressors. We analyzed the Env expression, the fusion and cell-to-cell transfer capacities as well as viral infectivity. The sequence and phylogenetic analysis of

14 Envs were also performed. In every functional characteristic, the Envs from subjects with viral control (LTNP-ECs and vLTNPs) showed significant lower

16 performance compared to those from the progressor individuals (Old and

17 Modern). Regarding sequence analysis, the variable loops of the gp120 subunit

18 of the Env (i.e., V2, V4 and mainly V5) of the progressor individuals showed

19 longer and more glycosylated sequences than controller subjects. Therefore,

20 HIV-1 Envs presenting poor viral functions and shorter sequences were 21 associated with viremic control and the non-progressor clinical phenotype, 22 whereas functional Envs were associated with the lack of virological control and 23 progressor clinical phenotypes. These correlations support the central role of Env 24 genotypic and phenotypic characteristics in the in vivo HIV-1 infection and 25 pathogenesis. 


\section{7 \\ IMPORTANCE}

28 The role of the virus in the pathogenesis of HIV-1 infection has not been

29 investigated in isolates from individuals with different progression rates. In this

30 work, we studied the properties of the envelope glycoprotein complex (Env) in

31 individuals with different progression rates to elucidate its role in pathogenesis.

32 We estimated the Env expression, the CD4 binding, the fusion and cell-to-cell

33 viral transfer capacities that affect the infectivity of the viral Envs in recombinant

34 viruses. The Envs from individuals which control viral replication and lack

35 clinical progression (LTNP-ECs and VLTNPs) showed lower functional capacities

36 than from subjects with clinical progression (Old and Modern). The functional

37 increase of the Envs characteristics was associated with an increase in viral

38 infectivity and in increased length of variable loops and the number of

39 glycosylation sites of the Env (gp120/SU). These results support the concept

40 that viral characteristics contribute to viral infection and pathogenesis.

41 Words: 148 


\section{Introduction}

52 Pathogenesis of viral infections is the result of complex interactions between host genetics, immune responses and viral factors. In human immunodeficiency virus tye 1 (HIV-1) infection and pathogenesis, the role of host (1-6), immune (615) and viral factors (16-20) has been widely investigated. The interactions of these factors have been primarily studied in extreme clinical phenotypes like rapid progressors (RPs) $(21,22)$ or long-term non-progressors (LTNPs), LTNP23, 24).

Due to these entangled interactions, the investigation of the role of viral proteins and their specific properties in HIV-1 pathogenesis is challenging. Among the viral proteins, the envelope glycoprotein complex (Env) has attracted numerous studies because its essential role in the immune response and in the initial events of the HIV-1 biological cycle (25-29), i.e the binding to the cellular receptors (29-42). The binding efficiency of the viral Env to the CD4 receptor determines further steps of the viral cycle: virus-cell signaling, fusion and cell-tocell virus transfer capabilities $(18,19,43)$. HIV-1 Envs unable to stabilize microtubules (i.e., increasing post-transductional acetylation of Lys ${ }^{40}$ residue in $\alpha$-tubulin), to reorganize F-actin for the delineation of pseudopod-entry virus hot zones present low CD4 binding, restricted fusion and low early infection $(18,19$, 43-45).

There are few reports investigating the characteristics of viral Envs from HIV individuals with different clinical characteristics. Lassen et al. studied the entry efficiency of viral Envs from ES individuals relative to chronically infected viremic and chronic progressors. Envs from ES showed decreased entry efficacy and slower entry kinetics than those of chronic progressors (20). Our 
77 group studied the CD4 binding, signaling capacity, fusogenicity of viral Envs

78 from viremic non-progressors (VNPs) that were similar to those of progressors

79 individuals (19). In previous reports, deficient viral Env glycoproteins, because

80 of poor CD4 binding, low transfer and signaling capacity (18) were identified in a

81 cluster of poor replicating viruses from a group of LTNP-ECs without clinical

82 progression for more than 20 years $(17,18)$. Thus, these works have stablished

83 that viral Env play an important role in the pathogenesis control in LTNPs (17-

$8420,46,47)$.

85 To further investigate the role of viral Env in HIV-1 infection and pathogenesis,

86 in this work, we expanded our previous studies to viral Envs from other sets of

87 LTNP-ECs and Viremic LTNPs (vLTNPs) in comparison with groups of chronic progressors. Clonal full-length env genes derived from viruses of individuals in these distinct clinical groups were analyzed for expression, CD4 dependent-

90 Env-mediated fusion, cell-to-cell viral transfer and infection efficiency. This

91 analysis permitted the establishment of a relationship between the initial events

92 of the viral replication cycle, mediated by the viral Env characteristics, with the

93 VL control and the clinical outcome and pathogenesis of the HIV-1 infection. 


\section{Results}

97 Analysis of the characteristics of viral envelopes of viruses from different 98 risk groups.

99 For the investigation of the potential role of the HIV-1 Env in virological control

100 and pathogenesis, we studied the phenotypic characteristics of 41 Envs from 24

101 individuals without antiviral therapy and different VLs (Table 1). We analyzed 10

102 Envs from 6 LTNP-EC individuals with undetectable VL and infected in the late 103 80's and 90's; 10 viral clones from 6 Viremic LTNPs (VLTNPs) with VL $<10,000$

104 viral copies/mL and infected in the 90's. To ascertain that the characteristics of

105 the Envs from these LTNPs were not due to the sampling time, we compared

106 them with 10 Envs obtained from 6 HIV-1 individuals also infected in the same

107 period (90's), but with high $\mathrm{VL}>10^{5}$ viral copies/mL and chronic infection; these

108 Env were designated Old. Finally, we studied 11 viral clones from 6 chronic

109 individuals infected between 2013-2014 with VL $>10^{4}$ viral copies $/ \mathrm{mL}$ and named

110 Modern. The main characteristics of the participants are summarized in Table

1111.

112 We first analyzed the potential differences in the expression between the Env

113 clones from the clinical groups, by measuring their cell-surface expression

114 levels in HEK-293T cells (Figure 1A, shows study scheme, and Figure 2).

115 Although we observed a progressive augmentation of Env expression in viral

116 clones derived from patients that do not control viremia (i.e., Old and Modern

117 patients) compared to LTNPs (EC and Viremic), this increase did not reach

118 statistical significance (Figure 2). Thus, the expression capability of the viral

119 Envs appears to not contribute to the differences in VL and pathogenesis

120 between groups. 


\section{Analysis of cell-to-cell membrane fusion and viral transfer capacity of viral}

\section{3 envelopes.}

124 A key process for HIV Env-mediated infection is the interaction of the Env

125 complex with the CD4 receptor. When this interaction is functionally efficient,

126 viral transfer through synaptic contacts or fusion pore formation are triggered

127 during cell-to-cell or virus-to-cell contacts, repectively $(18,19,43,45,48)$. We

128 examined the viral Env/CD4 interaction and the efficiency of subsequent

129 functions, measuring the membrane fusion capacity of the Envs (Figure 1B,

130 shows study scheme) in co-cultures between Env-expressing HEK-293T and

131 HIV-permissive target TZM-bl cells (Figure 3). To fully characterize our experimental models, we used the Envs from reference HIV-1 $1_{\mathrm{BaL}}$ (CCR5-tropic) and HIV-1 ${ }_{\text {NL4.3 }}$ (CXCR4-tropic) viruses (Figure 3 and 4). This fusion assay

134 yielded lower fusion values for Envs of viruses from LTNP-ECs and from

135 vLTNPs than for Old and Modern progressors, and attaining statistical

136 significance between LTNPs (EC and Viremic) and Modern Envs glycoproteins

137 (Figure 3B).

138 Next, we assayed the CD4-dependent cell-to-cell virus transfer capacity of the

139 viral envelopes. This experiment was performed co-culturing Env-expressing

140 HEK-293T cells with unstimulated primary CD4+ T lymphocytes as target cells

141 (Figure 1C, shows study scheme, and Materials and methods). In this assay,

142 we forced the formation of virological synapses between virus-effector HEK-

143 293T cells expressing the different Envs together with the structural HIV Gag

144 polyprotein, and fresh primary CD4+ T cells from healthy donors (Figure 1C,

145 shows study scheme). The Envs from the LTNPs (EC and Viremic) individuals

146 displayed a lower ability to transfer viral particles to primary CD4+ T

147 lymphocytes than Envs from Old individuals and significantly lower than from 
148 Modern participants ( $p<0.0022$ between all groups) (Figure 4). These data

149 suggest that the Envs from LTNP-EC viruses had an impaired binding to the

150 cell-surface CD4 receptor and that this impairment was progressively overcome

151 in the Envs from individuals from the other groups with less control of viral

152 replication, and higher VL.

153 Thus, the phenotypic characterization of the Envs of viruses from subjects with

154 distinct progression rates confirmed that LTNP-ECs and VLTNPs presented

155 viruses with an impaired Env CD4-associated functions and a significant lower

156 fusogenic and transfer capacity, in comparison with viruses from the viremic

157 groups: These lower characteristics were also linked with the low VL detected in

158 these subjects (Figures 3 and 4). We also observed a functional improvement

159 in the viral Envs from the LTNP-EC and vLTNP individuals to those of chronic

160 Modern glycoproteins: These data support that the deficient Env fusion and

161 transfer capacities observed in the Envs of viruses from LTNP-EC and vLTNP

162 phenotypes have been enhanced in the viruses from individuals with

163 progressive infection, particularly in those of the Modern group.

Infectivity of recombinant viruses with the analyzed envelopes.

166 For the exploration of the potential consequences of these Env properties in

167 virus biology, we estimated the infectivity of recombinant viruses bearing the

168 Env from the different HIV+ phenotypic groups in TZM-bl cells (Figure 5 and

169 Figure 1D, shows study scheme). Viral Envs from the LTNP-EC group showed

170 the lowest infectivity values, whereas the Modern Envs produced the higher

171 titers. The viruses from vLTNPs displayed higher titers than LTNP-ECs but

172 lower than those from Old individuals. Recombinant viruses from individuals

173 with high VL and progressive infection (Old and Modern) have higher infectivity 
174 rates than those with viral control (EC and Viremic). These results explain why

175 the viral properties analyzed (binding, fusion and transfer) have a significant

176 impact in viral infectivity with an important effect in the biology of HIV-1 and viral

177 pathogenesis.

178

179 Correlation between viral characteristics of the envelopes.

180 A significant correlation was observed between the HIV-1 Env-triggered cell-to-

181 cell transfer data, which is directly mediated by Env/CD4 binding, with Env-

182 mediated infectivity and fusogenicity (Figure 6). In all viral characteristics, the

183 Envs from subjects with virological control (EC and Viremic) showed the lower

184 values, whereas those from the non-controlling individuals (Old and Modern)

185 had the higher values. Therefore, HIV-1 Envs displaying poor viral functions,

186 because of the poor binding of the viral Env to the CD4, correlated with viremic

187 control and non-progressor clinical phenotypes. In contrast, functional Envs are

188 associated with the lack of viremic control and the progressor clinical

189 phenotypes. These statistical correlations support the role of viral properties in

190 the viral phenotype that contributes to HIV-1 infection, disease progression and

191 pathogenesis.

193 Analysis of the viral envelope sequences.

194 For the search of potential mechanisms involved in the changes of the

195 characteristics among the different Envs sets, we analyzed the Env amino-acid

196 (aa) sequences that could be associated with the distinct clinical phenotypes.

197 Initially, we performed a phylogenetic reconstruction from env aa sequences

198 together with other aa sequences obtained from HIV-1 Spanish individuals. All

199 aa sequences analized correspond to HIV-1 subtype B. This analysis did not 
reveal phylogenetic relationships between the different groups analysed and no clustering except for those aa sequences obtained from the same individual

202 (Figure 7). Envs from LTNP-ECs and one vLTNPs grouped in short branches,

203 as a consequence of the viral and evolutionary control, whereas long branch

204 length was observed in the sequences obtained from non-controller patients

205 (Old and Modern), because of the higher replication and viral evolution in these 206 individuals.

207 We then carried out a comprehensive study of the protein sequences focusing 208 in the variable loops and their associated potential $\mathrm{N}$-linked glycosylation sites

209 (PNGs) in the gp120 subunit of the Env. In general, as previously reported,

210 there is a trend in the HIV-1 viral Env to gain length and glycosylation sites

211 along the epidemic (49-51). This increasing trend is also found in our work

212 where viruses from the LTNPs (EC, Viremic) and Old Envs isolated in the 90's

213 showed shorter lengths than those of the Modern group obtained in 2013-2014

214 (Table 2). The V3 loop was the most conserved and constant region in length

215 and glycosylation sites (Table 2 and Figure 8), while the other loops showed

216 length increases predominantly in the V2 and V5 loops that were reproduced in

217 the total length (Table 2 and Figure 8). The only statistical differences were

218 noticed between the total length in the LTNPs (EC and Viremic) versus Old and

219 Modern Envs in the V2 and V5 regions (Figure 8).

220 Regarding the PNGS in the sequences, many of the 24 relevant sites previously

221 described (52-55) were present in these set of viral glycoproteins. However,

222 major differences were observed in the aa extension of the loops with a

223 progressive acquisition of more PNGS in the Modern Envs (Table 2). Glycan at

224 N289 site was more present in LTNP-ECs, vLTNPs and Old viruses but is not

225 present in Modern ones. Position N362 which is N proximal to the CD4 binding 
“DPE” motif (positions 368-370HXB2 sequence) was conserved in LTNP-EC,

227 Viremic and Old but was only present in two of the Modern Envs. It is interesting

228 to highlight that changes also occurred in the viral transmembrane gp41 protein

229 in glycan N816 that was dominant in LTNPs but not in chronic individuals (Old

230 and Modern).

231 It is interesting to mention that the trend in Env length increase follows the same

232 pattern that the functional growth of the Env shown in the distinct viral

233 characteristics (see Figures 3 to 6). We observed a good correlation between

234 the genetic distance to the subtype B ancestor sequence obtained from Los

235 Alamos National Laboratory HIV Database (LANL database,

236 http://www.hiv.lanl.gov) and the functionality of viral Env proteins analysed

237 (Figure 9). In general, the lower evolutionary sequences (less genetic distance

238 to subtype B ancestor) are those with lower functionality (LTNP-ECs) and the

239 higher evolutionary sequences are those with higher functionality (Moderns). In

240 summary, the viral Envs with the most efficient characteristics are found within

241 the Envs of the Modern group that also show the longer gp160 proteins, with

242 more glycosylated sites and higher distance to the subtype B ancestor. 


\section{Discussion}

246 HIV-1 infected individuals display a wide spectrum of clinical progression rates.

247 The causes of this dispersion are multiple and associated with the operation of

248 numerous combinations of host genetic, immunological and viral factors. In this

249 work, we studied the potential contribution of viral Env glycoprotein

250 characteristics to the clinical outcome of HIV-1 infection in HIV+ individuals with

251 different clinical status.

252 The different groups of patients were defined by their clinical characteristics,

253 distinct VLs and isolation dates because several studies have described a clear

254 correlation between patients' VL and the likelihood of virus transmission,

255 disease progression and pathogenesis (56-63).

256 Although viral control in HIV-1 individuals has been linked to the host-immune

257 responses $(10,64)$, other researchers and our group, however, stablished, in

258 previous works, a direct connection between deficiencies in HIV-1 Env-

259 associated functions and long-term viremia control in $\operatorname{LTNP}$-ECs $(17,18,20)$.

260 The Envs from these LTNP-EC individuals were ineffective in the CD4 binding

261 and in the subsequent functions: viral signaling, fusion and cell entry. These

262 Env characteristics ensued in low replication and transmissibility of the virus

$263(18,19,43,45)$. All these data strongly support the role of the viral Env in the

264 LTNP-EC phenotype and viral pathogenesis.

265 In the present work, we extended these observations to more Env from non-

266 progressor subjects, which are not associated with a cluster of infection, in

267 comparison to different sets of progressor chronic individuals. The Envs

268 characteristics from LTNP individuals (EC and Viremic) were compared with

269 those of individuals with progressive infection (Old and Modern). We 
270 investigated the defects in the association of Envs with the CD4, membrane

271 fusion impairment and the cell-to-cell virus transfer and viral infection capacities.

272 Viral Envs from LTNPs showed the lower binding capacity to the CD4 receptor

273 and this initial inefficient Env/CD4 interaction led to a deficiency in membrane

274 fusion and virus cell-to-cell transfer capabilities. The properties of the Env from

275 LTNPs were not due to the ancestral origin of the LTNPs viruses isolated in the

276 late 80's and 90's, because the chacteristics of the Old viruses which were

277 contemporary to the LTNPs did not showed these limited functional

278 characteristics. On the contrary, Envs from progressors (Old and Modern)

279 presented efficient CD4-mediated viral functionality that triggered an effective

280 membrane fusion and viral transfer. Thus, we disclosed that there is a clear

281 correlation between the level of viral fusion, the transfer capacity of the viral Env

282 and viral infectivity. The observed differences between the characteristics of the

283 Envs from these groups could not be associated with viral tropism, because all

284 the env nucleotide sequences from the studied viruses, showed an R5 tropism

285 (Web PSSM, https://indra.mullins.microbiol.washington.edu/webpssm/ ).

286 In summary, viral Envs from LTNPs exhibited non-functional characteristics

287 (Figures 3-6) in comparison with those from viruses of the progressive infection

288 groups, supporting the concept that the properties of the Envs were associated

289 with viral control and the clinical progression rate of the HIV-1 individuals.

290 In spite of the limited sampling, because of the difficult and laborious viral

291 characterization of the viral phenotypes, we observed statistically significant

292 differences between the characteristics of the Envs of viruses from LTNP-ECs

293 and the Moderns. Also, if we consider the Env characteristics from all clinical

294 groups, there is a consistent and recurrent tendency, although with no statistical

295 power in some cases, to gain functionality in the viral Envs from the LTNP 
individuals (LTNP-ECs and vLTNPs), to those of the progressive groups (Old

297 and Modern).

298 Remarkably, the increase in Env functionality also correlated with longer and

299 more glycosylated proteins. The aa length and PNGs' profile of the Envs from

300 the individuals of the distinct clinical groups showed that the studied Envs tend

301 to increase length and glycosylation over the course of the epidemic as

302 previously described (see $(49,51))$. We observed that Env changes

303 accumulated essentially in the V1, V2, V4 and V5 loops, as previously shown in

304 works relating the role of V1 and V4 loops in the CD4 binding and neutralization

305 (65-68) and viral cell-to-cell transfer capacity $(50,69,70)$. Regarding specific

306 changes detected in our study, the loss of the N362 PNGs (position in the HXB2

307 isolate; group M, subtype B (HIV-1 M:B_HXB2R: NCBI:txid11706)) which was

308 prevalent in the EC, Viremic and Old but not in the Modern Envs groups could

309 be associated with the gain of functionality in the Envs. However, the opposite

310 effect with more efficient fusion and transfer capacity was found in Australian

311 viruses with the N362 glycosylation site (55). The potential role of the other

312 changes in PNGs detected in our study need to be further investigated. Besides

313 these important changes, it is clear that point mutations could have a significant

314 impact in the viral characteristics and HIV pathogenesis $(71,72)$. The variants

315 of concern (VOCs) of the pandemic severe acute respiratory syndrome

316 coronavirus (SARS-CoV-2) unfortunately are reminding us $(73,74)$. Thus, the

317 contribution of the individual mutations deserves further studies but it is now out

318 of the scope of the present work.

319 In contrast with the more significative changes detected in the V2 and V5 loops,

320 it is important to point the stability in length and glycosylation of the V3 loop.

321 This structure is key for viral tropism (75-79) and for the correct CD4 Env 
binding as revealed with anti-V3 neutralizing antibodies that abrogate Env-CD4

323 interaction $(80,81)$.

324 In this study, we confirmed the inefficient functionality of the Envs from LTNP-

325 EC individuals previously described for a cluster of viruses $(18,20)$, but

326 extended to HIV+ individuals controlling viremia which are not clustered by the

327 same transmitted/founder (T/F) virus. Also, a gain of Envs functionality from

328 those of the LTNP individuals to the chronic not controlling individuals was

329 identified. This improvement was detected in every Env characteristic analyzed;

330 expression, fusion, virus transfer and infectivity. Interestingly, this functional

331 growth of viral Env was associated in this study with length and PNGs increases

332 in the variable loops. This increase was also reported in studies analyzing the

333 susceptibility, neutralization sensitivity, co-receptor binding, host range and viral

334 phenotype (49). This increase in the V1-V2 length and PNGs has also been

335 detected thorough chronic infections from early to late viral Env sampling like in

336 our work (49). Likewise in a group of individuals infected with closely related

337 viruses higher PNGs density has been observed in the V1-V5 region of the

338 gp120 during chronic infection compared to those oberved during the early

339 acute infection phase (82). In viruses from the HIV-1 subtype B, it seems that

340 early after viral transmission to a new host a selection for viral variants with

341 shorter variable regions and a reduced degree of PNGs occurs (83). The growth

342 in functionality of the viral characteristics was also correlated with the genetic

343 distance of the sequences to the subtype B ancestor. Genetic variability in env

344 gene has been is associated with an increase in viral infectivity and replication

345 capacity (84-89). These changes could facilitate viral replication by increasing

346 viral fitness that favors the escape from the immune response and anti-retroviral

347 therapy (ART) failure (90-99). 
348 The non-functional characteristics of the primary Envs of LTNP individuals (ECs

349 and Viremics) resulted in poor viral replication and very limited evolution that

350 could allow the efficient immune control of HIV-1 infection and pathogenesis. It

351 has been reported that in a LTNP-EC patient that followed discontinued ART,

352 the V1 domain of his HIV-1 strain that retained good infectivity and replicative

353 capacity included two additional $\mathrm{N}$-glycosylation sites and was placed in the top

$3541 \%$ of lengths among the 6,112 Env sequences analyzed in the Los Alamos

355 National Laboratory online database (100).

356 Therefore, it is conceivable that the functional characterization of the inefficient

357 HIV-1 Envs could be significant in the development of a new generation of

358 immunogens. Indeed, attenuated HIV or simian immunodeficiency virus (SIV)

359 vaccines (LAHVs or LASVs) have been postulated as therapeutic vaccine

360 strategies (101-107). However, further antigenic and immunogenicity work is

361 needed to disclose the potential implications of these non-functional HIV Envs

362 in the vaccine/cure field.

364 In summary, in this work, we exposed that the characteristics of the viral Envs

365 from different groups of HIV-1 infected individuals could be associated with the

366 short or long-term VL control and the clinical progression rate of the infection.

367 The non-functional HIV-1 Envs could help in the development of new strategies

368 for functional cure and virus eradication. Our data support the hypothesis that

369 the functionality of viral Envs is a crucial characteristic for the control of viral

370 infection, replication and pathogenesis. 


\section{Material and methods}

\section{Viral envelopes.}

375 Forty-one viral envelopes (Envs) were obtained from samples of different

376 origins: the HIV HGM BioBank integrated in the Spanish AIDS Research

377 Network (RIS-RETIC, ISCIII) (samples $1,2,3,6,7,8,13,14,15,16,17,18,19$ ), the

378 Centro Sanitario Sandoval, Hospital Clínico San Carlos (samples

$37921,22,24,28,30,31,32,33,36,37,38,39,40,42,43,44,45,46,49,50,51,52)$, the

380 irsiCaixa Research Foundation (samples 9,10,11,12) and from Hospital Xeral

381 de Vigo (samples 26,27). Samples were obtained in three different phases of

382 the Spanish epidemic from 1993-94, 2004-2005 and 2013-2014. Samples were

383 processed following current procedures and frozen immediately after their

384 reception. All patients participating in the study gave their informed consent and

385 protocols were approved by institutional ethical committees. Identification

386 numbers and characteristics are found in Table1.

388 Ethics Statement.

389 Samples were obtained from participants who gave informed consent for

390 genetic analysis studies and they were registered as sample collection in the

391 Spanish National Registry of Biobanks for Biomedical Research with number

392 C.0004030. The consents were approved by the Ethical and Investigation

393 Committees of the "Centro Sanitario Sandoval" (Madrid) and the samples were

394 encoded and de-identified in these Centers. All clinical investigations were

395 conducted according to the principles expressed in the Declaration of Helsinki.

396 The studies were approved by the Comité de Ética de la Investigación y de

397 Bienestar Animal of the Instituto de Salud Carlos III with CEI PI 05_2010-v3 and

398 CEI PI 09-2013 numbers. 
399 Generation of env gene expression plasmids.

400 The env genes were amplified at limiting dilution by nested PCR from proviral

401 DNA. The products were cloned into the pcDNA3.1D/V5-His's Topo expression

402 vector (Invitrogen) and NL4.3. The R5-tropic BaL.01-env (catalog number

403 11445) glycoprotein plasmid was from the NIH AIDS Research and Reference

404 Reagent Program. Ten viral Envs were derived from 6 LTNP-EC patients, 10

405 clones from 6 Viremic LTNPs, 10 clones from 6 "Old" individuals (contemporary

406 to LTNPs) and 11 clones from 10 recent "Modern" patients and NL4.3 and

407 BaL.01 reference clones expression plasmids were transformed in $\mathrm{DH} 5 \alpha$ cells,

408 and clones sequenced to check the correct insertion of the env gene.

410 Env expression and fusion assays.

411 The Env expression plasmids were used to transfect HEK-293T cells with X-

412 tremeGENE HP DNA Transfection Reagent (Sigma) in combination with either

413 a Tat expression plasmid pTat for Env expression and fusion assays, or with the

414 env defective HIV-1 backbone pSG3 plasmid for viral transfer assays $(18,19$,

415 108). As a negative control, HEK-293T cells were transfected only with pTat

416 and as a positive control we use the BaL and NL4.3 Envs. HEK-293T cells were

417 chosen as effector cells since they provide sensitive measures of fusion even

418 when using low fusogenic Env. 24 hours post-transfection, cells were collected,

419 and tested for Env surface expression and also fusion activity.

420 To test Env expression, $1 \times 10^{5}$ Env/Tat co-transfected HEK-293T cells were

421 incubated with 2G12 and IgGb12 monoclonal antibodies (mAbs; Polymun,

422 Viena, Austria) at $6 \mu \mathrm{g} / \mathrm{mL}$ each for 45 minutes at RT. After washing the cells,

423 the PE-labeled goat anti-human IgG (Jackson ImmunoResearch Laboratories)

424 was added and incubated in the dark at room temperature for 15 minutes, as 
425 similarly reported $(18,19)$. Cells were washed, fixed in formaldehyde $1 \%$,

426 acquired in a Celesta flow cytometer (BD FACS Celesta) and analyzed using

427 the Flow-Jo software (Tree Star Inc.) The percentage of Env-positive cells and

428 the Mean Fluorescence Intensity (MFI) of these cells were used to evaluate Env

429 expression.

430 To test fusion activity, $1 \times 10^{4}$ Env/Tat-transfected or control Tat-transfected

431 HEK-293T cells were mixed (ratio 1:1) in 96-well plates with

$432 \mathrm{CD}^{+} \mathrm{CXCR}^{+} \mathrm{CCR}^{+} \mathrm{TZM}$-bl reporter cells for 6 hours at $37^{\circ} \mathrm{C}$. Luciferase

433 activity was measured (Fluoroskan Accent, Labsystems) using Brite-Lite

434 (PerkinElmer) and normalized to BaL-Env-mediated fusion. NL4.3 and BaL-Env

435 expression plasmids were used as positive controls for Env staining and as

436 reference value for fusion activity $(\mathrm{BaL}=100 \%)$, as similarly reported $(19,108)$

437 (summarized in the scheme of Figure 1B).

439 HIV-1 transfer/CD4 binding

440 To test viral transfer activity, which exclusively depends on the binding of gp120

441 to the CD4 molecule, Env expression plasmids were co-transfected with the

442 Env-defective pSG3 plasmid in HEK-293T cells, as similarly reported (18, 19,

443 108). One day after transfection, $1 \times 10^{5}$ HEK-293T cells were mixed at a $1: 1$

444 ratio in 96-well plates with primary CD4+ T lymphocytes freshly isolated from

445 healthy donors by negative selection (CD4+ T-Cell Isolation Kit II, human,

446 Miltenyi Biotec). Viral transfer was assessed after 24 hours of incubation at

$44737^{\circ} \mathrm{C}$ in permeabilized (FIX \& PERM Cell Permeabilization kit, Invitrogen Life

448 Technologies) and stained cells with the anti-HIV-1 p24 KC57 mAb (anti HIV

449 core antigen RD1 labelled, IZASA) for 20 minutes in the dark at RT. Then, the

450 cells were washed and fixed in formaldehyde $1 \%$, and acquired in a Celesta 
451 flow cytometer (BD FACS Celesta) and the content of p24 in gated CD4+ T

452 cells and gated HEK-293T cells was analyzed using the Flow-Jo software (Tree

453 Star Inc.). The percentage of p24+ HEK-293T cells was used as a control for

454 transfection efficiency and was similar among all experiments. Since co-

455 receptor binding or fusion activity are not required for viral transfer, the

456 frequency of p24+/CD4+ T cells was a direct measure of the amounts of HIV-1

457 virions bound to or taken up by target cells (summarized in the scheme of

458 Figure 1C).

$460 \quad$ Infectivity assay

461 Cloned viral Envs were used to generate pseudoviruses by co-transfection with 462 pSG3 plasmid of HEK-293T cells as indicated above and tested in TZM-bl cells

463 to determine the infectivity capacity. Serial Dilutions of the pseudoviruses

464 generated with the different Envs of the different groups of patients were made 465 in a 96-well plate. Then, $1 \times 10^{5} \mathrm{TZM}-\mathrm{bl}$ cells were added to the pseudoviruses 466 with DEAE dextran hydrochloride (Sigma) at $18 \mu \mathrm{g} / \mathrm{mL}$. After 48 hours of 467 incubation at $37^{\circ} \mathrm{C}$, luciferase activity was measured (Fluoroskan Accent, 468 Labsystems) using Brite-Lite (PerkinElmer). Uninfected TZM-bl cells were used 469 as a negative control. The TCID $_{50}$ (Median Tissue Culture Infectious Dose)

470 value was calculated with Montefiori template and normalized with the viral

471 concentrations (summarized in the scheme of Figure 1D).

473 Phylogenetic Analysis.

474 The evolutionary history was inferred by using the "maximum likelihood" (ML)

475 method and JTT matrix-based model (109). The tree with the highest log

476 likelihood $(-49687,86)$ is shown. The percentage of trees in which the 
477 associated taxa clustered together is shown next to the branches. Initial tree(s)

478 for the heuristic search was(were) obtained automatically by applying Neighbor-

479 Join and BioNJ algorithms to a matrix of pairwise distances estimated using the

480 JTT model, and then selecting the topology with superior log likelihood value. A

481 discrete Gamma distribution was used to model evolutionary rate differences

482 among sites ( 5 categories $(+G$, parameter $=0,6825))$. The rate variation model

483 allowed for some sites to be evolutionarily invariable $([+1], 18,05 \%$ sites $)$. The

484 tree is drawn to scale, with branch lengths measured in the number of

485 substitutions per site. This analysis involved 140 aa sequences. All positions

486 with less than $95 \%$ site coverage were eliminated (i.e., fewer than $5 \%$ alignment

487 gaps), and missing data and ambiguous bases were allowed at any position

488 (partial deletion option). There were a total of 829 positions in the final dataset.

489 Evolutionary analyses were conducted in MEGA X (110).

490 Nucleotide sequences have been deposited in GeneBank under the following

491 numbers: KC595156, KC595162, KC595225, KC595227, KC 595189,

492 MH605987, MH605986, KC595190, MH605988, MH605992, MH605991,

493 MH605970, MH605971, KC595223, KC595222, MH605972, MH605975,

494 MH605976, MH605978, MH605973, MH605979, MH605980, MH605981,

495 MH605982, MH605983, MH605984, MK394184, MK394185.

497 Statistical analysis.

498 Data and statistical analyses were performed using GraphPad Prism, version

4996.07 (GraphPad Software). Significance when comparing groups was

500 determined with a nonparametric Kruskal-Wallis or by nonparametric Dunn's

501 test for multiple comparisons. A nonparametric Spearman test was used to

502 calculate correlations. 
bioRxiv preprint doi: https://doi.org/10.1101/2021.07.07.451566; this version posted July 9, 2021. The copyright holder for this preprint (which was not certified by peer review) is the author/funder, who has granted bioRxiv a license to display the preprint in perpetuity. It is made available under aCC-BY-NC-ND 4.0 International license.

\section{Data Availability}

504 All "accession numbers" and "data" of this work are available.

505

506 


\section{Acknowledgements}

508 We want to particularly acknowledge the patients in this study for their

509 participation and to the HIV BioBank integrated in the Spanish AIDS Research

510 Network and collaborating Centres ( http://hivhgmbiobank.com/donor-

511 area/hospitals-and-centres-transferring-samples/?lang=en ) for the generous

512 gifts of clinical samples used in this work. The HIV BioBank, integrated in the

513 Spanish AIDS Research Network, is partially funded by the RD16/0025/0019

514 project as part of the Plan Nacional $R+D+I$ and cofinanced by ISCIII-

515 Subdirección General de Evaluación and el Fondo Europeo de Desarrollo

516 Regional (FEDER). The clinical follow-up of Drs. Carmen Rodriguez, Mar Vera

517 and Jorge Del Romero (Centro Sanitario Sandoval), Eulalia Grau (Hospital

518 Germans, Trias y Pujol; irsiCaixa, Badalona) is greatly appreciated.

$520 \quad$ Funding

521 This work is supported by Spanish AIDS network "Red Temática Cooperativa

522 de Investigación en SIDA" RD12/0017/0002, RD12/0017/0028, RD12/0017/0034, RD16/0025/0011, RDCIII16/0002/0005 and RD16/0025/0041 as part of the Plan Nacional $\mathrm{R}+\mathrm{D}+\mathrm{I}$ and cofunded by Spanish "Instituto de Salud

525 Carlos III (ISCIII)-Subdirección General de Evaluación y el Fondo Europeo de

526 Desarrollo Regional (FEDER)". J.B. is a researcher from "Fundació Institut de

527 Recerca en Ciències de la Salut Germans Trias i Pujol" supported by the Health

528 Department of the Catalan Government/Generalitat de Catalunya and ISCIII

529 grant numbers PI17/01318 and PI20/00093 (to JB). Work in CL-G' and CC lab

530 was supported by grants SAF (2010-17226) and (2016-77894-R) from MINECO

531 (Spain) and FIS (PI 13/02269, ISCIII). A.V-F's Lab is supported by the

532 European Regional Development Fund (ERDF), RTI2018-093747-B-100 
533 (“Ministerio de Ciencia e Innovación”, Spain), “Ministerio de Ciencia, Innovación

534 y Universidades” (Spain), ProlD2020010093 (“Agencia Canaria de

535 Investigación, Innovación y Sociedad de la Información" and European Social

536 Fund), UNLL10-3E-783 (ERDF and "Fundación CajaCanarias") and "SEGAI-

537 ULL". S.P-Y is funded by "Fundación Doctor Manuel Morales" (La Palma,

538 Spain) and "Contrato Predoctoral Ministerio-ULL Formación de Doctores" (2019

539 Program) ("Ministerio de Ciencia, Innovación y Universidades”, Spain). R.C-R is

540 funded by RD16/0025/0011 and ProlD2020010093 (“Agencia Canaria de

541 Investigación, Innovación y Sociedad de la Información” and European Social

542 Fund). J-E-H is funded by the Cabildo Tenerife "Agustin de Betancourt" 2017

543 Program. 


\section{Figures legends}

547 Figure 1. Outline of the experimental model used for the analysis of Env expression, Env-mediated cell-to-cell fusion, viral transfer and viral infectivity. (A) Env expression: HEK-293T cells will be co-transfected with

550 primary of reference full-length viral env and a ptat $\Delta$ env HIV-1 expression

551 plasmid, allowing Env cell-surface expression in a viral production context. Cell-

552 surface Env expression will be then analyzed by flow cytometry using specific anti-Env antibody. (B) Env-mediated fusion activity: after 24 hours, effector HEK-293T cells producing HIV-1 particles bearing primary or reference Envs will be co-cultured with TZM-bl cells to force synapsis formation and CD4-

556 mediated binding of budding particles to target cells. (C) Env-mediated viral

557 transfer: HEK-293T cells producing HIV-1 particles carrying primary or

558 reference Envs will be co-cultured with primary CD4+ T cells. Then, HIV-1

559 transfer will be analyzed by flow cytometry using specific anti-p24 antibody in

560 target CD4+ T cells. (D) Env-mediated viral infection: TZM-bl cells will be

561 infected with serial dilutions of viral particles obtained from transfected HEK-

562 293T and carrying the different primary or reference HIV-1 Envs. After 48 hours, 563 infectivity capacity will be analyzed by quantifying luciferase assay in infected 564 TZM-bl cells.

566 Figure 2. Analysis of the expression of the different HIV-1-Env

567 glycoproteins from LTNP-EC, Viremic LTNP and control progressors

568 patients.

569 Flow cytometry analysis of the cell-surface expression level of the assayed HIV-

5701 Envs in HEK-293T cells from LTNP-EC (gray bars), vLTNP (green bars), Old

571 (orange bars) and Modern individuals (red bars) or reference HIV-1 viral strains 
572 (ptat, No Ab2, NL4.3 and BaL, black bars). Env protein expression for each

573 patient $(A)$ and Env protein expression in each group of patients comparing

574 mean values between each group (Kruskal-Wallis, Dunn's Multiple

575 Comparisons Test) (B); $p$ value for comparison between all groups is shown,

576 top left. Values are mean \pm S.E.M. of three independent experiments.

Figure 3. Analysis of membranes fusion-phenotypic features of HIV-1

579 Envs isolated from LTNP-EC, viremic LTNP and P individuals. Analysis of

580 the ability to induce cell-to-cell fusion of HIV-1 Env proteins obtained from

581 LTNP-EC (gray bars), vLTNP (green bars), Old (orange bars) and Modern

582 individuals (red bars) or reference HIV-1 viral strains (ptat, NL4.3 and BaL,

583 black bars). (A) Env fusogenic activity for each patient in each group. (B)

584 Relative fusion activity of the full Env collection compared to the BaL control

585 established at $100 \%$ and grouped in the different groups of patients. Values are

586 mean \pm S.E.M. of three independent experiments. Statistical analysis was

587 performed using Kruskal-Wallis, Dunn's Multiple Comparisons Test; $p$ value for

588 comparison between all groups is shown, top left.

590 Figure 4. Analysis of HIV-1 Env-mediated cell-to-cell viral transfer.

591 Analysis of the ability to induce cell-to-cell virus transfer of HIV-1 Env proteins obtained

592 from LTNP-EC (gray bars), vLTNP (green bars), Old Patients (orange bars), recent

593 patients (Moderns) (red bars) or reference HIV-1 viral strains (pSG3, CD4+ cells, NL4.3

594 and BaL, black bars). Analysis of HIV-1 Env-mediated cell-to-cell viral transfer for each

595 patient $(A)$ and in each group where $P$ values compare medians between groups using

596 a nonparametric Kruskal-Wallis Test (Kruskal-Wallis, Dunn's Multiple Comparisons 
597 Test) (B); $p$ value for comparison between all groups is shown, top left. Values

598 are mean \pm S.E.M. of two independent experiments.

599

600 Figure 5. Viral infectivity of the viral Envs.

601 Analysis of the infecivity ( $T_{C} I_{50}$ value normalized by viral p24 input) of the different of

602 HIV-1 Env proteins obtained from LTNP-EC (gray bars), vLTNP (green bars), Old

603 (orange bars) and Moderns (red bars) patients or reference HIV-1 viral strains (pSG3,

604 NL4.3 and BaL, black bars). Analysis of Env infectivity for each patient (A) and in each

605 group where $\mathrm{P}$ values compare medians between groups using a nonparametric

606 Kruskal-Wallis, Dunn's Multiple Comparisons Test (B); $\mathrm{p}$ value for comparison

607 between all groups is shown, top left. Values are mean \pm S.E.M. of three

608 independent experiments.

609

610 Figure 6. Analysis of the correlation of the fusion, transfer and viral

611 infectivity Env characteristics between groups.

612 (A) Correlation between Relative fusion and HIV Transfer of all Envs of the

613 different groups LTNP-EC (gray circle), vLTNP (green circle), Old patients

614 (orange square) and Modern patients (red square). The correlation was

615 calculated with a nonparametric Spearman test. (B) Correlation between

616 Relative fusion and Infectivity $\left(\mathrm{TCID}_{50}\right.$ value normalized by viral p24 input) of all

617 Envs of the different groups LTNP-EC (gray circle), vLTNP (green circle), Old

618 patients (orange square) and Modern patients (red square). The correlation was

619 calculated with a nonparametric Spearman test. (C) Correlation between

620 Infectivty and HIV Transfer of all Envs of the differents groups LTNP-EC (gray

621 circle), vLTNP (green circle), Old patients (orange square) and recent patients

622 Moderns) (red square) is shown. The correlation was calculated with a 
nonparametric Spearman test. Values are mean \pm S.E.M. of three independent experiments; $p$ value for comparison between all groups is shown, top left.

\section{Figure 7. Phylogenetic analysis of the vial Envs.}

627 The evolutionary history of the Env aa sequences was inferred as described in

628 Materials and Methods using the Maximum Likelihood method and JTT matrixbased model (109). The tree with the highest log likelihood $(-49687,86)$ is shown. The percentage of trees in which the associated taxa clustered together

631 is shown next to the branches. Evolutionary analyses were conducted in MEGA $632 \times(110)$.

634 Figure 8. Analysis of the length and glycosylation sites in the loops of the 635 Envs from the different groups.

636 Analysis of the length of each variable loops V1 (A), V2 (B), V3 (C), V4 (D), V5

637 (E) and all variable loops together $(F)$. The results were grouped (LTNP-ECs:

638 gray bar, vLTNPs: green bar, Old patients: orange bar, and recent patients

639 (Moderns): red bar) and compared using a nonparametric Kruskal-Wallis,

640 Dunn's Multiple Comparisons Test; $p$ value for comparison between all groups

641 is shown, top left. Values are mean \pm S.E.M. of three independent experiments.

643 Figure 9. Correlation of the expression, fusion, transfer and viral

644 infectivity Env characteristics with the nucleotide genetic distance to 645 subtype B ancestor.

646 Correlation between genetic distance to subtype B ancestor of all Envs of the 647 different groups and Env expression (A), Relative fusion (B), HIV Transfer (C) 648 and Infectivity (D). LTNP-ECs (gray circle), vLTNPs (green circle), Old patients 
649 (orange square) and Modern patients (red square). The correlations were

650 calculated with a nonparametric Spearman test ( $p$ and $r$ values are shown, top

651 left). Values of Env expression, Relative fusion, HIV transfer and Infectivity are

652 mean \pm S.E.M. of three independent experiments.

653

654 


\section{References}

656

657 1. Fellay J, Ge D, Shianna KV, Colombo S, Ledergerber B, Cirulli ET, Urban TJ, Zhang K, 658 Gumbs CE, Smith JP, Castagna A, Cozzi-Lepri A, De Luca A, Easterbrook P, Gunthard HF, 659 Mallal S, Mussini C, Dalmau J, Martinez-Picado J, Miro JM, Obel N, Wolinsky SM, Martinson 660 JJ, Detels R, Margolick JB, Jacobson LP, Descombes P, Antonarakis SE, Beckmann JS, O'Brien 661 SJ, Letvin NL, McMichael AJ, Haynes BF, Carrington M, Feng S, Telenti A, Goldstein DB, 662 Immunology NCfHAV. 2009. Common genetic variation and the control of HIV-1 in humans. 663 PLoS Genet 5:e1000791.

664 2. Naranbhai V, Carrington M. 2017. Host genetic variation and HIV disease: from 665 mapping to mechanism. Immunogenetics 69:489-498.

666 3. Migueles SA, Sabbaghian MS, Shupert WL, Bettinotti MP, Marincola FM, Martino L, 667 Hallahan CW, Selig SM, Schwartz D, Sullivan J, Connors M. 2000. HLA B*5701 is highly 668 associated with restriction of virus replication in a subgroup of HIV-infected long term 669 nonprogressors. Proc Natl Acad Sci U S A 97:2709-2714.

670 4. Miura T, Brockman MA, Schneidewind A, Lobritz M, Pereyra F, Rathod A, Block BL, 671 Brumme ZL, Brumme CJ, Baker B, Rothchild AC, Li B, Trocha A, Cutrell E, Frahm N, Brander C, 672 Toth I, Arts EJ, Allen TM, Walker BD. 2009. HLA-B57/B*5801 human immunodeficiency virus 673 type 1 elite controllers select for rare gag variants associated with reduced viral replication 674 capacity and strong cytotoxic T-lymphocyte [corrected] recognition. J Virol 83:2743-2755.

675 5. Migueles SA, Connors M. 2015. Success and failure of the cellular immune response 676 against HIV-1. Nat Immunol 16:563-570.

677 6. Buckheit RW, 3rd, Allen TG, Alme A, Salgado M, O'Connell KA, Huculak S, Falade-

678 Nwulia O, Williams TM, Gallant JE, Siliciano RF, Blankson JN. 2012. Host factors dictate 679 control of viral replication in two HIV-1 controller/chronic progressor transmission pairs. Nat 680 Commun 3:716.

6817 7. Goulder P, Deeks SG. 2018. HIV control: Is getting there the same as staying there?

682 PLoS Pathog 14:e1007222.

683 8. Cortes FH, de Paula HHS, Bello G, Ribeiro-Alves M, de Azevedo SSD, Caetano DG, 684 Teixeira SLM, Hoagland B, Grinsztejn B, Veloso VG, Guimaraes ML, Morgado MG. 2018. 685 Plasmatic Levels of IL-18, IP-10, and Activated CD8(+) T Cells Are Potential Biomarkers to 686 Identify HIV-1 Elite Controllers With a True Functional Cure Profile. Front Immunol 9:1576.

687 9. Martin-Gayo E, Buzon MJ, Ouyang Z, Hickman T, Cronin J, Pimenova D, Walker BD, 688 Lichterfeld M, Yu XG. 2015. Potent Cell-Intrinsic Immune Responses in Dendritic Cells Facilitate 689 HIV-1-Specific T Cell Immunity in HIV-1 Elite Controllers. PLoS Pathog 11:e1004930.

690 10. Deeks SG, Walker BD. 2007. Human immunodeficiency virus controllers: mechanisms 691 of durable virus control in the absence of antiretroviral therapy. Immunity 27:406-416.

692 11. Pernas M, Casado C, Arcones C, Llano A, Sanchez-Merino V, Mothe B, Vicario JL, Grau 693 E, Ruiz L, Sanchez J, Telenti A, Yuste E, Brander C, Galindez CL. 2012. Low-replicating viruses 694 and strong anti-viral immune response associated with prolonged disease control in a 695 superinfected HIV-1 LTNP elite controller. PLoS One 7:e31928. 
696 12. Carrington M, Walker BD. 2012. Immunogenetics of spontaneous control of HIV. Annu

697 Rev Med 63:131-145.

698 13. Migueles SA, Osborne CM, Royce C, Compton AA, Joshi RP, Weeks KA, Rood JE,

699 Berkley AM, Sacha JB, Cogliano-Shutta NA, Lloyd M, Roby G, Kwan R, McLaughlin M, Stallings

700 S, Rehm C, O'Shea MA, Mican J, Packard BZ, Komoriya A, Palmer S, Wiegand AP, Maldarelli F,

701 Coffin JM, Mellors JW, Hallahan CW, Follman DA, Connors M. 2008. Lytic granule loading of

$702 \mathrm{CD} 8+\mathrm{T}$ cells is required for HIV-infected cell elimination associated with immune control.

703 Immunity 29:1009-1021.

704 14. Goulder PJ, Phillips RE, Colbert RA, McAdam S, Ogg G, Nowak MA, Giangrande P, 705 Luzzi G, Morgan B, Edwards A, McMichael AJ, Rowland-Jones S. 1997. Late escape from an 706 immunodominant cytotoxic T-lymphocyte response associated with progression to AIDS. Nat 707 Med 3:212-217.

708 15. Buckheit RW, 3rd, Salgado M, Silciano RF, Blankson JN. 2012. Inhibitory potential of 709 subpopulations of CD8+ T cells in HIV-1-infected elite suppressors. J Virol 86:13679-13688.

710 16. Blankson JN. 2010. Effector mechanisms in HIV-1 infected elite controllers: highly 711 active immune responses? Antiviral Res 85:295-302.

712 17. Casado C, Pernas $M$, Sandonis V, Alvaro-Cifuentes T, Olivares I, Fuentes R, Martinez713 Prats L, Grau E, Ruiz L, Delgado R, Rodriguez C, del Romero J, Lopez-Galindez C. 2013.

714 Identification of a cluster of HIV-1 controllers infected with low replicating viruses. PLoS One 715 8:e77663.

716 18. Casado C, Marrero-Hernandez S, Marquez-Arce D, Pernas M, Marfil S, Borras717 Granana F, Olivares I, Cabrera-Rodriguez R, Valera MS, de Armas-Rillo L, Lemey P, Blanco J, 718 Valenzuela-Fernandez A, Lopez-Galindez C. 2018. Viral Characteristics Associated with the 719 Clinical Nonprogressor Phenotype Are Inherited by Viruses from a Cluster of HIV-1 Elite 720 Controllers. mBio 9.

721 19. Cabrera-Rodriguez R, Hebmann V, Marfil S, Pernas M, Marrero-Hernandez S, Cabrera C, Urrea V, Casado C, Olivares I, Marquez-Arce D, Perez-Yanes S, Estevez-Herrera J, Clotet B, Espert L, Lopez-Galindez C, Biard-Piechaczyk M, Valenzuela-Fernandez A, Blanco J. 2019. HIV1 envelope glycoproteins isolated from Viremic Non-Progressor individuals are fully functional 725 and cytopathic. Sci Rep 9:5544.

726 20. Lassen KG, Lobritz MA, Bailey JR, Johnston S, Nguyen S, Lee B, Chou T, Siliciano RF, 727 Markowitz M, Arts EJ. 2009. Elite suppressor-derived HIV-1 envelope glycoproteins exhibit 728 reduced entry efficiency and kinetics. PLoS Pathog 5:e1000377.

729 21. Dalmau J, Puertas MC, Azuara M, Marino A, Frahm N, Mothe B, Izquierdo-Useros N, 730 Buzon MJ, Paredes R, Matas L, Allen TM, Brander C, Rodrigo C, Clotet B, Martinez-Picado J. 731 2009. Contribution of immunological and virological factors to extremely severe primary HIV 732 type 1 infection. Clin Infect Dis 48:229-238.

733 22. Jarrin I, Pantazis N, Dalmau J, Phillips AN, Olson A, Mussini C, Boufassa F, Costagliola D, Porter K, Blanco J, Del Amo J, Martinez-Picado J. 2015. Does rapid HIV disease progression prior to combination antiretroviral therapy hinder optimal CD4+ T-cell recovery once HIV-1 736 suppression is achieved? Aids 29:2323-2333.

737 23. Casado C, Galvez C, Pernas M, Tarancon-Diez L, Rodriguez C, Sanchez-Merino V, Vera 738 M, Olivares I, De Pablo-Bernal R, Merino-Mansilla A, Del Romero J, Lorenzo-Redondo R, Ruiz- 
739 Mateos E, Salgado M, Martinez-Picado J, Lopez-Galindez C. 2020. Permanent control of HIV-1

740 pathogenesis in exceptional elite controllers: a model of spontaneous cure. Sci Rep 10:1902.

$741 \quad 24 . \quad$ Lopez-Galindez C, Pernas M, Casado C, Olivares I, Lorenzo-Redondo R. 2019. Elite

742 controllers and lessons learned for HIV-1 cure. Curr Opin Virol 38:31-36.

743 25. Checkley MA, Luttge BG, Freed EO. 2011. HIV-1 envelope glycoprotein biosynthesis, 744 trafficking, and incorporation. J Mol Biol 410:582-608.

745 26. Berger EA. 2015. Finding Fusin/CXCR4, the First "2nd Receptor" for HIV Entry. Front 746 Immunol 6:283.

747 27. Miedema F, Meyaard L, Koot M, Klein MR, Roos MT, Groenink M, Fouchier RA, Van't

748 Wout AB, Tersmette M, Schellekens PT, et al. 1994. Changing virus-host interactions in the

749 course of HIV-1 infection. Immunol Rev 140:35-72.

750 28. Beitari S, Wang Y, Liu SL, Liang C. 2019. HIV-1 Envelope Glycoprotein at the Interface of Host Restriction and Virus Evasion. Viruses 11.

752 29. Engelman A, Cherepanov P. 2012. The structural biology of HIV-1: mechanistic and therapeutic insights. Nat Rev Microbiol 10:279-290.

754 30. Chan DC, Kim PS. 1998. HIV entry and its inhibition. Cell 93:681-684.

755 31. Wyatt R, Sodroski J. 1998. The HIV-1 envelope glycoproteins: fusogens, antigens, and

756 immunogens. Science 280:1884-1888.

757 32. Alkhatib G, Combadiere C, Broder CC, Feng Y, Kennedy PE, Murphy PM, Berger EA.

758 1996. CC CKR5: a RANTES, MIP-1alpha, MIP-1beta receptor as a fusion cofactor for

759 macrophage-tropic HIV-1. Science 272:1955-1958.

760 33. Choe H, Farzan M, Sun Y, Sullivan N, Rollins B, Ponath PD, Wu L, Mackay CR, LaRosa

761 G, Newman W, Gerard N, Gerard C, Sodroski J. 1996. The beta-chemokine receptors CCR3 and

762 CCR5 facilitate infection by primary HIV-1 isolates. Cell 85:1135-1148.

763 34. Oberlin E, Amara A, Bachelerie F, Bessia C, Virelizier JL, Arenzana-Seisdedos F, 764 Schwartz O, Heard JM, Clark-Lewis I, Legler DF, Loetscher M, Baggiolini M, Moser B. 1996.

765 The CXC chemokine SDF-1 is the ligand for LESTR/fusin and prevents infection by T-cell-line-

766 adapted HIV-1. Nature 382:833-835.

767 35. Feng Y, Broder CC, Kennedy PE, Berger EA. 1996. HIV-1 entry cofactor: functional

768 cDNA cloning of a seven-transmembrane, G protein-coupled receptor. Science 272:872-877.

769 36. Deng H, Liu R, Ellmeier W, Choe S, Unutmaz D, Burkhart M, Di Marzio P, Marmon S, 770 Sutton RE, Hill CM, Davis CB, Peiper SC, Schall TJ, Littman DR, Landau NR. 1996. Identification 771 of a major co-receptor for primary isolates of HIV-1. Nature 381:661-666.

772 37. Dalgleish AG, Beverley PC, Clapham PR, Crawford DH, Greaves MF, Weiss RA. 1984. 773 The CD4 (T4) antigen is an essential component of the receptor for the AIDS retrovirus. Nature 774 312:763-767.

775 38. Klatzmann D, Champagne E, Chamaret S, Gruest J, Guetard D, Hercend T, Gluckman 776 JC, Montagnier L. 1984. T-lymphocyte T4 molecule behaves as the receptor for human 777 retrovirus LAV. Nature 312:767-768. 
39. Blanco J, Valenzuela A, Herrera C, Lluís C, Hovanessian AG, Franco R. 2000. The HIV-1 gp120 inhibits the binding of adenosine deaminase to CD26 by a mechanism modulated by CD4 and CXCR4 expression. FEBS Lett 477:123-128.

40. Garcia-Perez J, Staropoli I, Azoulay S, Heinrich JT, Cascajero A, Colin P, Lortat-Jacob H, Arenzana-Seisdedos F, Alcami J, Kellenberger E, Lagane B. 2015. A single-residue change in the HIV-1 V3 loop associated with maraviroc resistance impairs CCR5 binding affinity while increasing replicative capacity. Retrovirology 12:50.

41. Colin P, Bénureau Y, Staropoli I, Wang Y, Gonzalez N, Alcami J, Hartley O, Brelot A, Arenzana-Seisdedos F, Lagane B. 2013. HIV-1 exploits CCR5 conformational heterogeneity to escape inhibition by chemokines. Proc Natl Acad Sci U S A 110:9475-9480.

42. Herschhorn A, Gu C, Moraca F, Ma X, Farrell M, Smith AB, 3rd, Pancera $M$, Kwong PD, Schön A, Freire E, Abrams C, Blanchard SC, Mothes W, Sodroski JG. 2017. The $\beta 20-\beta 21$ of gp120 is a regulatory switch for HIV-1 Env conformational transitions. Nat Commun 8:1049.

43. Valenzuela-Fernandez A, Alvarez S, Gordon-Alonso M, Barrero M, Ursa A, Cabrero JR, Fernandez G, Naranjo-Suarez S, Yanez-Mo M, Serrador JM, Munoz-Fernandez MA, SanchezMadrid F. 2005. Histone deacetylase 6 regulates human immunodeficiency virus type 1 infection. Mol Biol Cell 16:5445-5454.

44. Garcia-Exposito L, Ziglio S, Barroso-Gonzalez J, de Armas-Rillo L, Valera MS, Zipeto D, Machado JD, Valenzuela-Fernandez A. 2013. Gelsolin activity controls efficient early HIV-1 infection. Retrovirology 10:39.

45. Barrero-Villar M, Cabrero JR, Gordon-Alonso M, Barroso-Gonzalez J, Alvarez-Losada S, Munoz-Fernandez MA, Sanchez-Madrid F, Valenzuela-Fernandez A. 2009. Moesin is required for HIV-1-induced CD4-CXCR4 interaction, F-actin redistribution, membrane fusion and viral infection in lymphocytes. J Cell Sci 122:103-113.

46. Kafando A, Martineau C, El-Far M, Fournier E, Doualla-Bell F, Serhir B, Kazienga A, Sangare MN, Sylla M, Chamberland A, Charest H, Tremblay CL. 2019. HIV-1 Envelope Glycoprotein Amino Acids Signatures Associated with Clade B Transmitted/Founder and Recent Viruses. Viruses 11.

47. Marconi V, Bonhoeffer S, Paredes R, Lu J, Hoh R, Martin JN, Deeks SG, Kuritzkes DR. 2008. Viral dynamics and in vivo fitness of HIV-1 in the presence and absence of enfuvirtide. J Acquir Immune Defic Syndr 48:572-576.

48. Blanco J, Bosch B, Fernandez-Figueras MT, Barretina J, Clotet B, Este JA. 2004. High level of coreceptor-independent HIV transfer induced by contacts between primary CD4 T cells. J Biol Chem 279:51305-51314.

49. Curlin ME, Zioni R, Hawes SE, Liu Y, Deng W, Gottlieb GS, Zhu T, Mullins JI. 2010. HIV1 envelope subregion length variation during disease progression. PLoS Pathog 6:e1001228.

50. Yuan T, Li J, Zhang MY. 2013. HIV-1 envelope glycoprotein variable loops are indispensable for envelope structural integrity and virus entry. PLoS One 8:e69789.

51. Sagar $\mathbf{M}, \mathbf{W u} \mathbf{X}$, Lee $\mathbf{S}$, Overbaugh J. 2006. Human immunodeficiency virus type 1 V1V2 envelope loop sequences expand and add glycosylation sites over the course of infection, and these modifications affect antibody neutralization sensitivity. J Virol 80:9586-9598. 
819 52. Gnanakaran S, Bhattacharya T, Daniels M, Keele BF, Hraber PT, Lapedes AS, Shen T,

820 Gaschen B, Krishnamoorthy M, Li H, Decker JM, Salazar-Gonzalez JF, Wang S, Jiang C, Gao F,

821 Swanstrom R, Anderson JA, Ping LH, Cohen MS, Markowitz M, Goepfert PA, Saag MS, Eron JJ,

822 Hicks CB, Blattner WA, Tomaras GD, Asmal M, Letvin NL, Gilbert PB, Decamp AC, Magaret

823 CA, Schief WR, Ban YE, Zhang M, Soderberg KA, Sodroski JG, Haynes BF, Shaw GM, Hahn BH,

824 Korber B. 2011. Recurrent signature patterns in HIV-1 B clade envelope glycoproteins

825 associated with either early or chronic infections. PLoS Pathog 7:e1002209.

826 53. Wang S, Voronin Y, Zhao P, Ishihara M, Mehta N, Porterfield M, Chen Y, Bartley C, Hu

827 G, Han D, Wells L, Tiemeyer M, Lu S. 2020. Glycan Profiles of gp120 Protein Vaccines from

828 Four Major HIV-1 Subtypes Produced from Different Host Cell Lines under Non-GMP or GMP

829 Conditions. J Virol 94.

830 54. Go EP, Irungu J, Zhang Y, Dalpathado DS, Liao HX, Sutherland LL, Alam SM, Haynes

831 BF, Desaire H. 2008. Glycosylation site-specific analysis of HIV envelope proteins (JR-FL and

832 CON-S) reveals major differences in glycosylation site occupancy, glycoform profiles, and

833 antigenic epitopes' accessibility. J Proteome Res 7:1660-1674.

834 55. Sterjovski J, Churchill MJ, Ellett A, Gray LR, Roche MJ, Dunfee RL, Purcell DF, Saksena

835 N, Wang B, Sonza S, Wesselingh SL, Karlsson I, Fenyo EM, Gabuzda D, Cunningham AL, Gorry

836 PR. 2007 . Asn 362 in gp120 contributes to enhanced fusogenicity by CCR5-restricted HIV-1

837 envelope glycoprotein variants from patients with AIDS. Retrovirology 4:89.

838 56. Coffin JM. 1995. HIV population dynamics in vivo: implications for genetic variation,

839 pathogenesis, and therapy. Science 267:483-489.

$840 \quad 57 . \quad$ Fideli US, Allen SA, Musonda R, Trask S, Hahn BH, Weiss H, Mulenga J, Kasolo F,

841 Vermund SH, Aldrovandi GM. 2001. Virologic and immunologic determinants of heterosexual

842 transmission of human immunodeficiency virus type 1 in Africa. AIDS Res Hum Retroviruses

$843 \quad$ 17:901-910.

$844 \quad 58 . \quad$ Hecht FM, Hartogensis W, Bragg L, Bacchetti P, Atchison R, Grant R, Barbour J, Deeks

845 SG. 2010. HIV RNA level in early infection is predicted by viral load in the transmission source.

846 AIDS 24:941-945.

847 59. Mellors JW, Kingsley LA, Rinaldo CR, Jr., Todd JA, Hoo BS, Kokka RP, Gupta P. 1995.

848 Quantitation of HIV-1 RNA in plasma predicts outcome after seroconversion. Ann Intern Med

$849 \quad 122: 573-579$.

850 60. Mellors JW, Rinaldo CR, Jr., Gupta P, White RM, Todd JA, Kingsley LA. 1996. Prognosis

851 in HIV-1 infection predicted by the quantity of virus in plasma. Science 272:1167-1170.

852 61. Pilcher CD, Joaki G, Hoffman IF, Martinson FE, Mapanje C, Stewart PW, Powers KA,

853 Galvin S, Chilongozi D, Gama S, Price MA, Fiscus SA, Cohen MS. 2007. Amplified transmission

854 of HIV-1: comparison of HIV-1 concentrations in semen and blood during acute and chronic

855 infection. AIDS 21:1723-1730.

856 62. Quinn TC, Wawer MJ, Sewankambo N, Serwadda D, Li C, Wabwire-Mangen F,

857 Meehan MO, Lutalo T, Gray RH. 2000. Viral load and heterosexual transmission of human

858 immunodeficiency virus type 1. Rakai Project Study Group. N Engl J Med 342:921-929.

859 63. Yue L, Prentice HA, Farmer P, Song W, He D, Lakhi S, Goepfert P, Gilmour J, Allen S,

860 Tang J, Kaslow RA, Hunter E. 2013. Cumulative impact of host and viral factors on HIV-1 viral-

861 load control during early infection. J Virol 87:708-715. 
862 64. Balasubramaniam M, Pandhare J, Dash C. 2019. Immune Control of HIV. J Life Sci

863 (Westlake Village) 1:4-37.

864 65. van Gils MJ, Bunnik EM, Boeser-Nunnink BD, Burger JA, Terlouw-Klein M, Verwer N,

865 Schuitemaker H. 2011. Longer V1V2 region with increased number of potential N-linked

866 glycosylation sites in the HIV-1 envelope glycoprotein protects against HIV-specific neutralizing

867 antibodies. J Virol 85:6986-6995.

868 66. Rong R, Bibollet-Ruche F, Mulenga J, Allen S, Blackwell JL, Derdeyn CA. 2007. Role of

869 V1V2 and other human immunodeficiency virus type 1 envelope domains in resistance to

870 autologous neutralization during clade C infection. J Virol 81:1350-1359.

871 67. Moore PL, Gray ES, Choge IA, Ranchobe N, Mlisana K, Abdool Karim SS, Williamson C, 872 Morris L. 2008. The c3-v4 region is a major target of autologous neutralizing antibodies in 873 human immunodeficiency virus type 1 subtype C infection. J Virol 82:1860-1869.

874 68. Castro E, Bélair M, Rizzardi GP, Bart PA, Pantaleo G, Graziosi C. 2008. Independent 875 evolution of hypervariable regions of HIV-1 gp120: V4 as a swarm of N-Linked glycosylation 876 variants. AIDS Res Hum Retroviruses 24:106-113.

877 69. Davenport YW, West AP, Jr., Bjorkman PJ. 2016. Structure of an HIV-2 gp120 in 878 Complex with CD4. J Virol 90:2112-2118.

879 70. Wang L, Izadmehr S, Kamau E, Kong XP, Chen BK. 2019. Sequential trafficking of Env 880 and Gag to HIV-1 T cell virological synapses revealed by live imaging. Retrovirology 16:2.

881 71. Mishra N, Makhdoomi MA, Sharma S, Kumar S, Dobhal A, Kumar D, Chawla H, Singh

882 R, Kanga U, Das BK, Lodha R, Kabra SK, Luthra K. 2019. Viral Characteristics Associated with

883 Maintenance of Elite Neutralizing Activity in Chronically HIV-1 Clade C-Infected Monozygotic

884 Pediatric Twins. J Virol 93.

885 72. Coffin J, Swanstrom R. 2013. HIV pathogenesis: dynamics and genetics of viral

886 populations and infected cells. Cold Spring Harb Perspect Med 3:a012526.

887 73. Andreano E, Rappuoli R. 2021. SARS-CoV-2 escaped natural immunity, raising

888 questions about vaccines and therapies. Nat Med 27:759-761.

889 74. Garcia-Beltran WF, Lam EC, St Denis K, Nitido AD, Garcia ZH, Hauser BM, Feldman J, 890 Pavlovic MN, Gregory DJ, Poznansky MC, Sigal A, Schmidt AG, lafrate AJ, Naranbhai V, Balazs 891 AB. 2021. Multiple SARS-CoV-2 variants escape neutralization by vaccine-induced humoral 892 immunity. Cell 184:2372-2383.e2379.

893 75. Bieniasz PD, Fridell RA, Aramori I, Ferguson SS, Caron MG, Cullen BR. 1997. HIV-1-

894 induced cell fusion is mediated by multiple regions within both the viral envelope and the CCR-

895 co-receptor. Embo j 16:2599-2609.

896 76. Isaka Y, Sato A, Miki S, Kawauchi S, Sakaida H, Hori T, Uchiyama T, Adachi A, Hayami

897 M, Fujiwara T, Yoshie O. 1999. Small amino acid changes in the V3 loop of human

898 immunodeficiency virus type 2 determines the coreceptor usage for CXCR4 and CCR5. Virology

$899 \quad 264: 237-243$.

900 77. Cocchi F, DeVico AL, Garzino-Demo A, Cara A, Gallo RC, Lusso P. 1996. The V3 domain

901 of the HIV-1 gp120 envelope glycoprotein is critical for chemokine-mediated blockade of

902 infection. Nat Med 2:1244-1247. 
903

904

905

906

907

908

909

910

911

912

913

914

915

916

917

918

919

920

921

922

923

924

925

926

927

928

929

930

931

932

933

934

935

936

937

938

939

940

941

942

943

944

945

78. Speck RF, Wehrly K, Platt EJ, Atchison RE, Charo IF, Kabat D, Chesebro B, Goldsmith MA. 1997. Selective employment of chemokine receptors as human immunodeficiency virus type 1 coreceptors determined by individual amino acids within the envelope V3 loop. J Virol 71:7136-7139.

79. Wu L, Gerard NP, Wyatt R, Choe H, Parolin C, Ruffing N, Borsetti A, Cardoso AA, Desjardin E, Newman W, Gerard C, Sodroski J. 1996. CD4-induced interaction of primary HIV-1 gp120 glycoproteins with the chemokine receptor CCR-5. Nature 384:179-183.

80. Trkola A, Dragic T, Arthos J, Binley JM, Olson WC, Allaway GP, Cheng-Mayer C, Robinson J, Maddon PJ, Moore JP. 1996. CD4-dependent, antibody-sensitive interactions between HIV-1 and its co-receptor CCR-5. Nature 384:184-187.

81. Valenzuela A, Blanco J, Krust B, Franco R, Hovanessian AG. 1997. Neutralizing antibodies against the V3 loop of human immunodeficiency virus type 1 gp120 block the CD4dependent and -independent binding of virus to cells. J Virol 71:8289-8298.

82. Pollakis $G$, Baan $E$, van Werkhoven MB, Berkhout $B$, Bakker $M$, Jurriaans $S$, Paxton WA. 2015. Association between gp120 envelope V1V2 and V4V5 variable loop profiles in a defined HIV-1 transmission cluster. Aids 29:1161-1171.

83. Liu Y, Curlin ME, Diem K, Zhao H, Ghosh AK, Zhu H, Woodward AS, Maenza J, Stevens CE, Stekler J, Collier AC, Genowati I, Deng W, Zioni R, Corey L, Zhu T, Mullins JI. 2008. Env length and $\mathrm{N}$-linked glycosylation following transmission of human immunodeficiency virus Type 1 subtype B viruses. Virology 374:229-233.

84. Dang LVP, Pham HV, Dinh TT, Nguyen TH, Vu QTH, Vu NTP, Le PTB, Nguyen LV, Le HT, Vu PT, Olson L. 2020. Characterization of envelope sequence of HIV virus in children infected with HIV in Vietnam. SAGE Open Med 8:2050312120937198.

85. Fraser C, Lythgoe K, Leventhal GE, Shirreff G, Hollingsworth TD, Alizon S, Bonhoeffer S. 2014. Virulence and pathogenesis of HIV-1 infection: an evolutionary perspective. Science 343:1243727.

86. Fischer W, Ganusov VV, Giorgi EE, Hraber PT, Keele BF, Leitner T, Han CS, Gleasner CD, Green L, Lo CC, Nag A, Wallstrom TC, Wang S, McMichael AJ, Haynes BF, Hahn BH, Perelson AS, Borrow P, Shaw GM, Bhattacharya T, Korber BT. 2010. Transmission of single HIV-1 genomes and dynamics of early immune escape revealed by ultra-deep sequencing. PLoS One 5:e12303.

87. Quan Y, Liang C, Brenner BG, Wainberg MA. 2009. Multidrug-resistant variants of HIV type 1 (HIV-1) can exist in cells as defective quasispecies and be rescued by superinfection with other defective HIV-1 variants. J Infect Dis 200:1479-1483.

88. Roche M, Jakobsen MR, Sterjovski J, Ellett A, Posta F, Lee B, Jubb B, Westby M, Lewin SR, Ramsland PA, Churchill MJ, Gorry PR. 2011. HIV-1 escape from the CCR5 antagonist maraviroc associated with an altered and less-efficient mechanism of gp120-CCR5 engagement that attenuates macrophage tropism. J Virol 85:4330-4342.

89. Keele BF, Giorgi EE, Salazar-Gonzalez JF, Decker JM, Pham KT, Salazar MG, Sun C, Grayson T, Wang S, Li H, Wei X, Jiang C, Kirchherr JL, Gao F, Anderson JA, Ping LH, Swanstrom R, Tomaras GD, Blattner WA, Goepfert PA, Kilby JM, Saag MS, Delwart EL, Busch MP, Cohen MS, Montefiori DC, Haynes BF, Gaschen B, Athreya GS, Lee HY, Wood N, Seoighe C, Perelson AS, Bhattacharya T, Korber BT, Hahn BH, Shaw GM. 2008. Identification and characterization 
946

947

948

949

950

951

952

953

954

955

956

957

958

959

960

961

962

963

964

965

966

967

968

969

970

971

972

973

974

975

976

977

978

979

980

981

982

983

984

985

of transmitted and early founder virus envelopes in primary HIV-1 infection. Proc Natl Acad Sci U S A 105:7552-7557.

90. Hunt PW, Harrigan PR, Huang W, Bates M, Williamson DW, McCune JM, Price RW, Spudich SS, Lampiris H, Hoh R, Leigler T, Martin JN, Deeks SG. 2006. Prevalence of CXCR4 tropism among antiretroviral-treated HIV-1-infected patients with detectable viremia. J Infect Dis 194:926-930.

91. Moore PL, Gray ES, Morris L. 2009. Specificity of the autologous neutralizing antibody response. Curr Opin HIV AIDS 4:358-363.

92. Kassaye S, Johnston E, McColgan B, Kantor R, Zijenah L, Katzenstein D. 2009.

Envelope coreceptor tropism, drug resistance, and viral evolution among subtype C HIV-1infected individuals receiving nonsuppressive antiretroviral therapy. J Acquir Immune Defic Syndr 50:9-18.

93. Shi B, Kitchen C, Weiser B, Mayers D, Foley B, Kemal K, Anastos K, Suchard M, Parker M, Brunner C, Burger H. 2010. Evolution and recombination of genes encoding HIV-1 drug resistance and tropism during antiretroviral therapy. Virology 404:5-20.

94. Duenas-Decamp MJ, Peters P, Burton D, Clapham PR. 2008. Natural resistance of human immunodeficiency virus type 1 to the CD4bs antibody b12 conferred by a glycan and an arginine residue close to the CD4 binding loop. J Virol 82:5807-5814.

95. Salazar-Gonzalez JF, Bailes E, Pham KT, Salazar MG, Guffey MB, Keele BF, Derdeyn CA, Farmer P, Hunter E, Allen S, Manigart O, Mulenga J, Anderson JA, Swanstrom R, Haynes BF, Athreya GS, Korber BT, Sharp PM, Shaw GM, Hahn BH. 2008. Deciphering human immunodeficiency virus type 1 transmission and early envelope diversification by singlegenome amplification and sequencing. J Virol 82:3952-3970.

96. Kitrinos KM, Hoffman NG, Nelson JA, Swanstrom R. 2003. Turnover of env variable region 1 and 2 genotypes in subjects with late-stage human immunodeficiency virus type 1 infection. J Virol 77:6811-6822.

97. Kitrinos KM, Nelson JA, Resch W, Swanstrom R. 2005. Effect of a protease inhibitorinduced genetic bottleneck on human immunodeficiency virus type 1 env gene populations. J Virol 79:10627-10637.

98. Kitchen CM, Philpott S, Burger H, Weiser B, Anastos K, Suchard MA. 2004. Evolution of human immunodeficiency virus type 1 coreceptor usage during antiretroviral Therapy: a Bayesian approach. J Virol 78:11296-11302.

99. Koot M, Keet IP, Vos AH, de Goede RE, Roos MT, Coutinho RA, Miedema F, Schellekens PT, Tersmette M. 1993. Prognostic value of HIV-1 syncytium-inducing phenotype for rate of CD4+ cell depletion and progression to AIDS. Ann Intern Med 118:681-688.

100. Silver ZA, Dickinson GM, Seaman MS, Desrosiers RC. 2019. A Highly Unusual V1 Region of Env in an Elite Controller of HIV Infection. J Virol 93.

101. Desrosiers RC. 1998. Prospects for live attenuated HIV. Nat Med 4:982.

102. Almond N, Stott J. 1999. Live attenuated SIV--a model of a vaccine for AIDS. Immunol Lett 66:167-170. 
986 103. Johnson RP. 1999. Live attenuated AIDS vaccines: hazards and hopes. Nat Med 5:154-

987155.

988 104. Murphey-Corb M. 1997. Live-attenuated HIV vaccines: how safe is safe enough? Nat

989 Med 3:17-18.

$990105 . \quad$ Mills J, Desrosiers R, Rud E, Almond N. 2000. Live attenuated HIV vaccines: a proposal

991 for further research and development. AIDS Res Hum Retroviruses 16:1453-1461.

992 106. Baba TW, Liska V, Khimani AH, Ray NB, Dailey PJ, Penninck D, Bronson R, Greene MF, 993 McClure HM, Martin LN, Ruprecht RM. 1999. Live attenuated, multiply deleted simian

994 immunodeficiency virus causes AIDS in infant and adult macaques. Nat Med 5:194-203.

995 107. Blower SM, Koelle K, Kirschner DE, Mills J. 2001. Live attenuated HIV vaccines:

996 predicting the tradeoff between efficacy and safety. Proc Natl Acad Sci U S A 98:3618-3623.

997 108. Curriu M, Fausther-Bovendo H, Pernas M, Massanella M, Carrillo J, Cabrera C, Lopez-

998 Galindez C, Clotet B, Debre P, Vieillard V, Blanco J. 2012. Viremic HIV infected individuals with

999 high CD4 T cells and functional envelope proteins show anti-gp41 antibodies with unique

1000 specificity and function. PLoS One 7:e30330.

1001 109. Jones DT, Taylor WR, Thornton JM. 1992. The rapid generation of mutation data

1002 matrices from protein sequences. Comput Appl Biosci 8:275-282.

1003 110. Kumar S, Stecher G, Li M, Knyaz C, Tamura K. 2018. MEGA X: Molecular Evolutionary

1004 Genetics Analysis across Computing Platforms. Mol Biol Evol 35:1547-1549.

1005

1006

1007 
bioRxiv preprint doi: https://doi.org/10.1101/2021.07.07 451566: this version posted July 92021 . The copyright holder for this preprint (which was not certified by peer review) is the author/funder, who has granted bioRxiv a license to display the preprint in perpetuity. It is made available under aCC-BY-NC-ND 4.0 International license.

Table 1. Epidemiological, clinical and host characteristics of the viral Envs.

\begin{tabular}{|c|c|c|c|c|c|c|c|c|}
\hline $\begin{array}{l}\text { Clinical } \\
\text { Group }\end{array}$ & Sub-group & $\begin{array}{c}\text { Env } \\
\text { code }^{a}\end{array}$ & $\begin{array}{c}\text { Patient } \\
\text { Identification } \\
\text { code } \\
\end{array}$ & $\begin{array}{l}\text { Viral Load }^{\mathrm{g}} \\
\text { (at sampling) }\end{array}$ & $\begin{array}{l}\text { Diagnostic } \\
\text { time }\end{array}$ & $\begin{array}{c}\text { Sampling } \\
\text { time }\end{array}$ & $\begin{array}{c}\text { Viral } \\
\text { dating }^{\mathrm{b}}\end{array}$ & HLA B \\
\hline \multirow[t]{20}{*}{ LTNP } & \multirow[t]{10}{*}{ EC } & 1 & 2057906-3 & $<50$ & 1993 & 2004 & 1989 & $4901 / 5701$ \\
\hline & & 2 & 3227050 & $<50$ & 1988 & 2004 & 1991 & $0702 / 5201$ \\
\hline & & 3 & $3227058-3$ & $<50$ & 1992 & 2004 & 1991 & $1402 / 1402$ \\
\hline & & 6 & 20044616-3 & $<50$ & 1998 & 2004 & 1999 & $1501 / 5703$ \\
\hline & & ${ }^{*} 7$ & 10246788 & $<50$ & 1992 & 2005 & 1993 & $4402 / 5701$ \\
\hline & & L8 & & $<50$ & “ & “ & “ & “ \\
\hline & & $\Gamma 9$ & $\mathrm{MDM}^{\mathrm{C}}$ & 507 & 1998 & 1996 & 1987 & $4402 / 3501$ \\
\hline & & 10 & c & $<50$ & “ & 2011 & 1996 & " \\
\hline & & 11 & c & $<50$ & $"$ & 2005 & " & $"$ \\
\hline & & L12 & c & $<50$ & “ & 2005 & “ & " \\
\hline & \multirow[t]{10}{*}{ Viremic } & 13 & 4022834 & 3.710 & 1994 & 2004 & ND & $1401 / 4403$ \\
\hline & & 14 & 9684 & 2.557 & 1998 & 2005 & 1994 & $1302 / 4001$ \\
\hline & & 15 & 2988465 & 2.286 & 1993 & 2004 & 1999 & $1402 / 2705$ \\
\hline & & $\Gamma 16$ & 38175 & 418 & 1996 & 2014 & 1999 & $2705 / 5801$ \\
\hline & & 17 & & & “ & " & " & “ \\
\hline & & 18 & & & $"$ & “ & “ & " \\
\hline & & L19 & & & $"$ & “ & “ & $"$ \\
\hline & & 21 & 30 & 7.597 & 1989 & 1998 & 2000 & $1501 / 3501$ \\
\hline & & $\Gamma 22$ & 64 & 11.926 & 1989 & 1999 & 1999 & $4402 / 4901$ \\
\hline & & $L_{24}$ & & “ & “ & 2002 & “ & “ \\
\hline \multirow[t]{21}{*}{ Progressor } & \multirow[t]{10}{*}{ Old } & $\Gamma 26$ & $\mathrm{~V} 10^{\mathrm{d}}$ & N.D. & 1993 & 1994 & 1999 & $4002 / 4402$ \\
\hline & & L27 & & & & “ & “ & \\
\hline & & 28 & V13 & N.D. & 1992 & 1994 & 1990 & $0702 / 1402$ \\
\hline & & $\Gamma 30$ & L10 & 89.000 & ---- & 1993 & 1993 & $1501 / 4901$ \\
\hline & & L31 & & “ & “ & " & " & " \\
\hline & & $\Gamma^{32}$ & L 11 & 42.000 & 1993 & 1993 & 2000 & $1801 / 5101$ \\
\hline & & $L_{33}$ & & " & “ & u" & " & " \\
\hline & & 「36 & $114^{d}$ & 130.000 & 1987 & 1994 & 2002 & $0702 / 3502$ \\
\hline & & $L_{37}$ & d & " & " & " & " & " \\
\hline & & 38 & 118 & 170.000 & 1991 & 1994 & 1990 & $1402 / 4403$ \\
\hline & \multirow[t]{11}{*}{ Modern } & $\Gamma 39$ & ESI 17A & 156.300 & 2014 & 2013 & $N \cdot A^{f}$ & $4201 / 4402$ \\
\hline & & L40 & & “ & “ & “ & & “ \\
\hline & & $\Gamma 42$ & ESI 39A & 137.700 & 2012 & 2014 & N.A. & $1517 / 3801$ \\
\hline & & L43 & & “ & “ & “ & & “ \\
\hline & & $\Gamma 44$ & ESI 41A & 129.700 & 2012 & 2014 & N.A. & $3503 / 5701$ \\
\hline & & L45 & & “ & “ & “ & & “ \\
\hline & & 46 & ESI $5 A 2$ & 49.107 & 2004 & 2007 & N.A. & $4102 / 4402$ \\
\hline & & $\Gamma 49$ & ESI $42 \mathrm{~A}$ & 11.510 & 2011 & 2014 & N.A. & $1402 / 4403$ \\
\hline & & L50 & & “ & “ & " & & “ \\
\hline & & $\Gamma 51$ & ESI $42 \mathrm{~B}$ & 41.090 & 2011 & 2014 & N.A. & $0702 / 1501$ \\
\hline & & L52 & & “ & “ & " & & " \\
\hline
\end{tabular}

1009

1010

1011

1012

1013

1014

1015

1016

1017

1018

1019

1020

1021

${ }^{a} H I V-1$ Env number used in this study and identification codes.

${ }^{b}$ According to Bello et al. (2004). J Gen Virol. Feb;85(Pt 2):399-407. doi: 10.1099/vir.0.19365O. PMID: 14769897.

${ }^{\circ}$ Double infected individual (Casado et al. (2007) J Infect Dis. 2007 Sep 15;196(6):895-9. doi: 10.1086/520885. Epub 2007 Aug 14. PMID: 17703421).

${ }^{d}$ Individuals with a short antiviral therapy (AZT (zidovudine) and DDI (didanosine) for V10 patient and AZT for 114 patient).

${ }^{e}$ The Modern Individuals have been infected within 3 years.

${ }^{f}$ N.A.:Not applicable.

${ }^{g}$ HIV RNA copies $/ m L$

"Envs isolated from the same patient are indicated by brackets.

": same value than above. 
Table 2. Molecular characteristics of HIV-1 Envs: sequence length and $\mathbf{N}$ potential glycosylation sites (PNGs) in the variable loops (Vn) of the gp120 subunit.

\begin{tabular}{|c|c|c|c|c|c|c|c|c|c|c|c|}
\hline $\begin{array}{l}\text { Clinical } \\
\text { Group }\end{array}$ & Subgroup & $\begin{array}{l}\text { Env } \\
\text { code }\end{array}$ & ${ }^{\mathrm{a}} \mathbf{V} 1 / \mathrm{G}$ & V2/G & V3/G & V4/G & V5/G & ${ }^{b} \Sigma V n / G$ & ${ }^{c}$ Mean/G & ${ }^{d}$ Gp160 & ${ }^{\mathrm{e}}$ Mean \\
\hline \multirow[t]{20}{*}{ LTNP } & \multirow[t]{10}{*}{ EC } & 1 & $28 / 4$ & $43 / 2$ & $37 / 2$ & $28 / 4$ & $12 / 1$ & $148 / 13$ & & 848 & \\
\hline & & 2 & $33 / 5$ & $41 / 2$ & $37 / 2$ & $31 / 4$ & $12 / 1$ & $154 / 14$ & & 853 & \\
\hline & & 3 & $33 / 5$ & $41 / 2$ & $37 / 2$ & $31 / 3$ & $12 / 2$ & $154 / 14$ & & 853 & \\
\hline & & 6 & $28 / 3$ & $41 / 2$ & $37 / 2$ & $34 / 4$ & $12 / 1$ & $152 / 12$ & & 852 & \\
\hline & & * 7 & $32 / 5$ & $47 / 2$ & $37 / 2$ & $30 / 4$ & $11 / 2$ & $157 / 15$ & $151.1 / 14.4$ & 859 & 851.8 \\
\hline & & L8 & $32 / 5$ & $47 / 2$ & $37 / 2$ & $30 / 4$ & $11 / 2$ & $157 / 15$ & & 859 & \\
\hline & & 「 9 & $24 / 4$ & $43 / 2$ & $36 / 2$ & $28 / 4$ & $12 / 1$ & $143 / 14$ & & 843 & \\
\hline & & 10 & $27 / 4$ & $42 / 2$ & $37 / 2$ & $29 / 5$ & $14 / 2$ & $149 / 16$ & & 851 & \\
\hline & & 11 & $27 / 5$ & $42 / 3$ & $37 / 2$ & $29 / 5$ & $13 / 2$ & $148 / 17$ & & 850 & \\
\hline & & L12 & $27 / 4$ & $42 / 3$ & $37 / 2$ & $32 / 5$ & $12 / 1$ & $150 / 14$ & & 850 & \\
\hline & \multirow[t]{10}{*}{ Viremic } & 13 & $31 / 5$ & $41 / 2$ & $37 / 2$ & $31 / 4$ & $13 / 1$ & $153 / 14$ & & 854 & \\
\hline & & 14 & $29 / 4$ & $42 / 2$ & $37 / 2$ & $32 / 5$ & $12 / 2$ & $152 / 15$ & & 852 & \\
\hline & & 15 & $34 / 5$ & $41 / 2$ & $37 / 2$ & $36 / 5$ & $12 / 1$ & $160 / 15$ & & 860 & \\
\hline & & $\Gamma 16$ & $29 / 5$ & $41 / 2$ & $37 / 1$ & $29 / 5$ & $12 / 1$ & $148 / 14$ & & 849 & \\
\hline & & 17 & $29 / 5$ & $41 / 2$ & $37 / 2$ & $29 / 5$ & $12 / 1$ & $148 / 16$ & $150,3 / 14.1$ & 849 & 851.5 \\
\hline & & 18 & $29 / 4$ & $41 / 2$ & $37 / 2$ & $29 / 5$ & $12 / 1$ & $148 / 15$ & & 849 & \\
\hline & & L19 & $29 / 4$ & $41 / 2$ & $37 / 2$ & $29 / 5$ & $12 / 1$ & $148 / 14$ & & 849 & \\
\hline & & 21 & $24 / 3$ & $41 / 2$ & $37 / 1$ & $30 / 5$ & $10 / 0$ & $142 / 11$ & & 842 & \\
\hline & & $\Gamma 22$ & $28 / 4$ & $41 / 2$ & $37 / 2$ & $32 / 5$ & $12 / 1$ & $150 / 14$ & & 850 & \\
\hline & & L24 & $37 / 7$ & $41 / 2$ & $36 / 2$ & $32 / 5$ & $12 / 1$ & $158 / 15$ & & 861 & \\
\hline \multirow[t]{16}{*}{ Progressor } & \multirow[t]{10}{*}{ Old } & 26 & $31 / 4$ & $41 / 3$ & $37 / 2$ & $39 / 7$ & $14 / 2$ & $160 / 18$ & & 862 & \\
\hline & & L27 & $31 / 5$ & $48 / 3$ & $37 / 2$ & $28 / 5$ & $14 / 2$ & $158 / 16$ & & 858 & \\
\hline & & 28 & $25 / 5$ & $41 / 2$ & $36 / 2$ & $33 / 5$ & $12 / 2$ & $145 / 15$ & & 848 & \\
\hline & & $\Gamma 30$ & $33 / 4$ & $41 / 2$ & $37 / 2$ & $27 / 4$ & $11 / 1$ & $150 / 14$ & & 852 & \\
\hline & & L31 & $33 / 5$ & $41 / 2$ & $37 / 2$ & $36 / 5$ & $13 / 2$ & $158 / 16$ & & 860 & \\
\hline & & $\Gamma 32$ & $28 / 5$ & $44 / 2$ & $36 / 2$ & $30 / 5$ & $15 / 2$ & $151 / 15$ & $153,8 / 15.2$ & 853 & 855.8 \\
\hline & & L33 & $31 / 4$ & $44 / 2$ & $36 / 2$ & $30 / 5$ & $15 / 2$ & $156 / 14$ & & 856 & \\
\hline & & 36 & $28 / 4$ & $46 / 1$ & $37 / 2$ & $34 / 5$ & $14 / 2$ & $157 / 15$ & & 859 & \\
\hline & & L37 & $28 / 4$ & $46 / 2$ & $37 / 2$ & $34 / 5$ & $14 / 2$ & $157 / 16$ & & 859 & \\
\hline & & 38 & $30 / 4$ & $41 / 3$ & $37 / 1$ & $31 / 4$ & $13 / 2$ & $150 / 13$ & & 851 & \\
\hline & \multirow[t]{6}{*}{ Modern $^{\mathrm{e}}$} & $\Gamma 39$ & $31 / 4$ & $41 / 2$ & $37 / 2$ & $29 / 4$ & $12 / 2$ & $149 / 14$ & & 849 & \\
\hline & & L40 & $31 / 4$ & $41 / 2$ & 37 & $29 / 4$ & $17 / 2$ & $154 / 14$ & & 849 & \\
\hline & & $\Gamma 42$ & $29 / 4$ & $48 / 2$ & 37 & $36 / 6$ & $17 / 2$ & $167 / 13$ & & 878 & \\
\hline & & L43 & $29 / 4$ & $48 / 3$ & 37 & $30 / 4$ & $15 / 2$ & $159 / 15$ & & 872 & \\
\hline & & $\Gamma 44$ & $28 / 4$ & $47 / 3$ & 37 & $31 / 4$ & $15 / 2$ & $158 / 15$ & $158.1 / 14.7$ & 859 & 862.0 \\
\hline & & L45 & $28 / 4$ & $47 / 2$ & 37 & $31 / 4$ & $15 / 2$ & $158 / 14$ & & 859 & \\
\hline
\end{tabular}


bioRxiv preprint doi: https://doi.org/10.1101/2021.07.07.451566; this version posted July 9, 2021. The copyright holder for this preprint (which was not certified by peer review) is the author/funder, who has granted bioRxiv a license to display the preprint in perpetuity. It is made available under aCC-BY-NC-ND 4.0 International license.

1025

1026

1027

1028

1029

1030

1031

1032

1033

1034

1035

1036

1037

1038

1039

1040

1041

1042

1043

1044

1045

1046

\begin{tabular}{|c|c|c|c|c|c|c|c|}
\hline 46 & $35 / 4$ & $46 / 3$ & 37 & $33 / 5$ & $13 / 2$ & $164 / 15$ & 865 \\
\hline$\Gamma 49$ & $37 / 6$ & $41 / 2$ & 37 & $42 / 7$ & $13 / 1$ & $170 / 18$ & 871 \\
\hline L50 & $37 / 6$ & $41 / 2$ & 37 & $42 / 7$ & $13 / 1$ & $170 / 18$ & 871 \\
\hline 551 & $31 / 4$ & $42 / 2$ & 37 & $26 / 3$ & $13 / 1$ & $149 / 12$ & 853 \\
\hline L52 & $29 / 4$ & $42 / 2$ & 37 & $32 / 6$ & $12 / 1$ & $152 / 15$ & 856 \\
\hline
\end{tabular}

${ }^{a}$ Length in amino acid (aa) and potential glycosylation sites (PNGs) of the Env-gp120 variable regions (Vn; from V1 to V5) expressed as Vn/G ratio.

${ } \Sigma V n / G$ indicates the sum of the aa lengths of the $V n$ ( $n$; from 1 to 5 ) and the potential $G$ sites.

${ }^{c} M e a n / G$ indicates the mean length and $P N G$ value for each group of Envs.

${ }^{d}$ Gp160 shows the total length in aa of each Env including the gp41 subunit and the gp120 subunit.

${ }^{\mathrm{e}}$ Mean gp160 length in aa for each group of Envs.

(1)

(1)

( 
bioRxiv preprint doi: https://doi org/10.1101/2021.07 07.451566; this version posted July 9,2021 . The copyright holder for this preprint (which was not certified by peer review) is the author/funder, who has granted bioRxiv a license to display the preprint in perpetuity. It is made available under aCC-BY-NC-ND 4.0 International license.

Table 1. Epidemiological, clinical and host characteristics of the viral Envs.

\begin{tabular}{|c|c|c|c|c|c|c|c|c|}
\hline $\begin{array}{l}\text { Clinical } \\
\text { Group }\end{array}$ & Sub-group & $\begin{array}{l}\text { Env } \\
\text { code }^{a}\end{array}$ & $\begin{array}{c}\text { Patient } \\
\text { Identification } \\
\text { code }\end{array}$ & $\begin{array}{l}\text { Viral Load }^{\mathrm{g}} \\
\text { (at sampling) }\end{array}$ & $\begin{array}{l}\text { Diagnostic } \\
\text { time }\end{array}$ & $\begin{array}{l}\text { Sampling } \\
\text { time }\end{array}$ & $\begin{array}{c}\text { Viral } \\
\text { dating }\end{array}$ & HLA B \\
\hline \multirow[t]{20}{*}{ LTNP } & \multirow[t]{10}{*}{ EC } & 1 & 2057906-3 & $<50$ & 1993 & 2004 & 1989 & $4901 / 5701$ \\
\hline & & 2 & 3227050 & $<50$ & 1988 & 2004 & 1991 & $0702 / 5201$ \\
\hline & & 3 & $3227058-3$ & $<50$ & 1992 & 2004 & 1991 & $1402 / 1402$ \\
\hline & & 6 & $20044616-3$ & $<50$ & 1998 & 2004 & 1999 & $1501 / 5703$ \\
\hline & & * 7 & 10246788 & $<50$ & 1992 & 2005 & 1993 & $4402 / 5701$ \\
\hline & & L8 & & $<50$ & “ & “ & “ & “ \\
\hline & & $\Gamma 9$ & $\mathrm{MDM}^{\mathrm{c}}$ & 507 & 1998 & 1996 & 1987 & $4402 / 3501$ \\
\hline & & 10 & c & $<50$ & “ & 2011 & 1996 & “ \\
\hline & & 11 & c & $<50$ & $"$ & 2005 & “ & $"$ \\
\hline & & L 12 & c & $<50$ & “ & 2005 & “ & “ \\
\hline & \multirow[t]{10}{*}{ Viremic } & 13 & 4022834 & 3.710 & 1994 & 2004 & ND & $1401 / 4403$ \\
\hline & & 14 & 9684 & 2.557 & 1998 & 2005 & 1994 & $1302 / 4001$ \\
\hline & & 15 & 2988465 & 2.286 & 1993 & 2004 & 1999 & $1402 / 2705$ \\
\hline & & $\Gamma 16$ & 38175 & 418 & 1996 & 2014 & 1999 & $2705 / 5801$ \\
\hline & & 17 & & & “ & “ & “ & “ \\
\hline & & 18 & & & “ & $"$ & " & $"$ \\
\hline & & L19 & & & $"$ & $"$ & $"$ & $"$ \\
\hline & & 21 & 30 & 7.597 & 1989 & 1998 & 2000 & $1501 / 3501$ \\
\hline & & $\Gamma 22$ & 64 & 11.926 & 1989 & 1999 & 1999 & $4402 / 4901$ \\
\hline & & $L_{24}$ & & “ & “ & 2002 & “ & " \\
\hline \multirow[t]{21}{*}{ Progressor } & \multirow[t]{10}{*}{ Old } & $\Gamma 26$ & $\mathrm{~V} 10^{\mathrm{d}}$ & N.D. & 1993 & 1994 & 1999 & $4002 / 4402$ \\
\hline & & L27 & & & & “ & “ & \\
\hline & & 28 & V13 & N.D. & 1992 & 1994 & 1990 & $0702 / 1402$ \\
\hline & & 30 & L10 & 89.000 & ---- & 1993 & 1993 & $1501 / 4901$ \\
\hline & & L31 & & " & $"$ & " & “ & “ \\
\hline & & $\Gamma^{32}$ & L 11 & 42.000 & 1993 & 1993 & 2000 & $1801 / 5101$ \\
\hline & & L33 & & “ & “ & "u & “ & “ \\
\hline & & $\Gamma 36$ & $114^{d}$ & 130.000 & 1987 & 1994 & 2002 & $0702 / 3502$ \\
\hline & & L 37 & d & " & “ & “ & “ & " \\
\hline & & 38 & 118 & 170.000 & 1991 & 1994 & 1990 & $1402 / 4403$ \\
\hline & \multirow[t]{11}{*}{ Modern } & 39 & ESI 17A & 156.300 & 2014 & 2013 & $N \cdot A^{f}$ & $4201 / 4402$ \\
\hline & & 40 & & “ & “ & “ & & “ \\
\hline & & $\Gamma 42$ & ESI 39A & 137.700 & 2012 & 2014 & N.A. & $1517 / 3801$ \\
\hline & & L43 & & “ & “ & “ & & “ \\
\hline & & $\Gamma 44$ & ESI 41A & 129.700 & 2012 & 2014 & N.A. & $3503 / 5701$ \\
\hline & & L45 & & “ & “ & “ & & “ \\
\hline & & 46 & ESI 5A 2 & 49.107 & 2004 & 2007 & N.A. & $4102 / 4402$ \\
\hline & & $\Gamma 49$ & ESI $42 \mathrm{~A}$ & 11.510 & 2011 & 2014 & N.A. & $1402 / 4403$ \\
\hline & & L50 & & " & “ & “ & & “ \\
\hline & & $\Gamma 51$ & ESI 42 B & 41.090 & 2011 & 2014 & N.A. & $0702 / 1501$ \\
\hline & & L52 & & “ & “ & " & & “ \\
\hline
\end{tabular}

${ }^{a} H I V-1$ Env number used in this study and identification codes.

${ }^{b}$ According to Bello et al. (2004). J Gen Virol. Feb;85(Pt 2):399-407. doi: 10.1099/vir.0.19365-0. PMID: 14769897.

${ }^{c}$ Double infected individual (Casado et al. (2007) J Infect Dis. 2007 Sep 15;196(6):895-9. doi: 10.1086/520885. Epub 2007 Aug 14. PMID: 17703421).

${ }^{d}$ Individuals with a short antiviral therapy (AZT (zidovudine) and DDI (didanosine) for V10 patient and AZT for I14 patient).

${ }^{e}$ The Modern Individuals have been infected within 3 years.

${ }^{f}$ N.A.:Not applicable.

${ }^{g}$ HIV RNA copies $/ m L$

"Envs isolated from the same patient are indicated by brackets.

": same value than above. 
bioRxiv preprint doi: https://doi.org/10.1101/2021.07.07.451566; this version posted July 9, 2021. The copyright holder for this preprint (which was not certified by peer review) is the author/funder, who has granted bioRxiv a license to display the preprint in perpetuity. It is made available under aCC-BY-NC-ND 4.0 International license. 
bioRxiv preprint doi: https://doi.org/10.1101/2021.07.07.451566; this version posted July 9,2021 . The copyright holder for this preprint (which was not certified by peer review) is the author/funder, who has granted bioRxiv a license to display the preprint in perpetuity. It is

Table 2. Molecular characteristics of Hil sites (PNGs) in the variable loops (Vn) of the gp120 subunit.

\begin{tabular}{|c|c|c|c|c|c|c|c|c|c|c|c|}
\hline Clinical Group & Subgroup & $\begin{array}{l}\text { Env } \\
\text { code }\end{array}$ & ${ }^{\mathrm{a}} \mathbf{V} \mathbf{1 / G}$ & V2/G & V3/G & V4/G & V5/G & ${ }^{b} \Sigma V n / G$ & ${ }^{c}$ Mean/G & ${ }^{d} G p 160$ & ${ }^{\mathrm{e}}$ Mean \\
\hline \multirow[t]{20}{*}{ LTNP } & EC & 1 & $28 / 4$ & $43 / 2$ & $37 / 2$ & $28 / 4$ & $12 / 1$ & $148 / 13$ & & 848 & \\
\hline & & 2 & $33 / 5$ & $41 / 2$ & $37 / 2$ & $31 / 4$ & $12 / 1$ & $154 / 14$ & & 853 & \\
\hline & & 3 & $33 / 5$ & $41 / 2$ & $37 / 2$ & $31 / 3$ & $12 / 2$ & $154 / 14$ & & 853 & \\
\hline & & 6 & $28 / 3$ & $41 / 2$ & $37 / 2$ & $34 / 4$ & $12 / 1$ & $152 / 12$ & & 852 & \\
\hline & & -7 & $32 / 5$ & $47 / 2$ & $37 / 2$ & $30 / 4$ & $11 / 2$ & $157 / 15$ & $151.1 / 14.4$ & 859 & 851.8 \\
\hline & & L8 & $32 / 5$ & $47 / 2$ & $37 / 2$ & $30 / 4$ & $11 / 2$ & $157 / 15$ & & 859 & \\
\hline & & 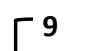 & $24 / 4$ & $43 / 2$ & $36 / 2$ & $28 / 4$ & $12 / 1$ & $143 / 14$ & & 843 & \\
\hline & & 10 & $27 / 4$ & $42 / 2$ & $37 / 2$ & $29 / 5$ & $14 / 2$ & $149 / 16$ & & 851 & \\
\hline & & 11 & $27 / 5$ & $42 / 3$ & $37 / 2$ & $29 / 5$ & $13 / 2$ & $148 / 17$ & & 850 & \\
\hline & & L12 & $27 / 4$ & $42 / 3$ & $37 / 2$ & $32 / 5$ & $12 / 1$ & $150 / 14$ & & 850 & \\
\hline & Viremic & 13 & $31 / 5$ & $41 / 2$ & $37 / 2$ & $31 / 4$ & $13 / 1$ & $153 / 14$ & & 854 & \\
\hline & & 14 & $29 / 4$ & $42 / 2$ & $37 / 2$ & $32 / 5$ & $12 / 2$ & $152 / 15$ & & 852 & \\
\hline & & 15 & $34 / 5$ & $41 / 2$ & $37 / 2$ & $36 / 5$ & $12 / 1$ & $160 / 15$ & & 860 & \\
\hline & & $\Gamma^{16}$ & $29 / 5$ & $41 / 2$ & $37 / 1$ & $29 / 5$ & $12 / 1$ & $148 / 14$ & & 849 & \\
\hline & & 17 & $29 / 5$ & $41 / 2$ & $37 / 2$ & $29 / 5$ & $12 / 1$ & $148 / 16$ & $150,3 / 14.1$ & 849 & 851.5 \\
\hline & & 18 & $29 / 4$ & $41 / 2$ & $37 / 2$ & $29 / 5$ & $12 / 1$ & $148 / 15$ & & 849 & \\
\hline & & L19 & $29 / 4$ & $41 / 2$ & $37 / 2$ & $29 / 5$ & $12 / 1$ & $148 / 14$ & & 849 & \\
\hline & & 21 & $24 / 3$ & $41 / 2$ & $37 / 1$ & $30 / 5$ & $10 / 0$ & $142 / 11$ & & 842 & \\
\hline & & 22 & $28 / 4$ & $41 / 2$ & $37 / 2$ & $32 / 5$ & $12 / 1$ & $150 / 14$ & & 850 & \\
\hline & & L24 & $37 / 7$ & $41 / 2$ & $36 / 2$ & $32 / 5$ & $12 / 1$ & $158 / 15$ & & 861 & \\
\hline \multirow[t]{21}{*}{ Progressor } & Old & $\Gamma 26$ & $31 / 4$ & $41 / 3$ & $37 / 2$ & $39 / 7$ & $14 / 2$ & $160 / 18$ & & 862 & \\
\hline & & ᄂ-27 & $31 / 5$ & $48 / 3$ & $37 / 2$ & $28 / 5$ & $14 / 2$ & $158 / 16$ & & 858 & \\
\hline & & 28 & $25 / 5$ & $41 / 2$ & $36 / 2$ & $33 / 5$ & $12 / 2$ & $145 / 15$ & & 848 & \\
\hline & & $\Gamma^{30}$ & $33 / 4$ & $41 / 2$ & $37 / 2$ & $27 / 4$ & $11 / 1$ & $150 / 14$ & & 852 & \\
\hline & & L31 & $33 / 5$ & $41 / 2$ & $37 / 2$ & $36 / 5$ & $13 / 2$ & $158 / 16$ & & 860 & \\
\hline & & $\Gamma 32$ & $28 / 5$ & $44 / 2$ & $36 / 2$ & $30 / 5$ & $15 / 2$ & $151 / 15$ & $153,8 / 15.2$ & 853 & 855.8 \\
\hline & & L33 & $31 / 4$ & $44 / 2$ & $36 / 2$ & $30 / 5$ & $15 / 2$ & $156 / 14$ & & 856 & \\
\hline & & $\Gamma 36$ & $28 / 4$ & $46 / 1$ & $37 / 2$ & $34 / 5$ & $14 / 2$ & $157 / 15$ & & 859 & \\
\hline & & L37 & $28 / 4$ & $46 / 2$ & $37 / 2$ & $34 / 5$ & $14 / 2$ & $157 / 16$ & & 859 & \\
\hline & & 38 & $30 / 4$ & $41 / 3$ & $37 / 1$ & $31 / 4$ & $13 / 2$ & $150 / 13$ & & 851 & \\
\hline & Modern $^{\mathrm{e}}$ & 39 & $31 / 4$ & $41 / 2$ & $37 / 2$ & $29 / 4$ & $12 / 2$ & $149 / 14$ & & 849 & \\
\hline & & L40 & $31 / 4$ & $41 / 2$ & 37 & $29 / 4$ & $17 / 2$ & $154 / 14$ & & 849 & \\
\hline & & {$[42$} & $29 / 4$ & $48 / 2$ & 37 & $36 / 6$ & $17 / 2$ & $167 / 13$ & & 878 & \\
\hline & & L43 & $29 / 4$ & $48 / 3$ & 37 & $30 / 4$ & $15 / 2$ & $159 / 15$ & & 872 & \\
\hline & & $\Gamma 44$ & $28 / 4$ & $47 / 3$ & 37 & $31 / 4$ & $15 / 2$ & $158 / 15$ & $158.1 / 14.7$ & 859 & 862.0 \\
\hline & & L45 & $28 / 4$ & $47 / 2$ & 37 & $31 / 4$ & $15 / 2$ & $158 / 14$ & & 859 & \\
\hline & & 46 & $35 / 4$ & $46 / 3$ & 37 & $33 / 5$ & $13 / 2$ & $164 / 15$ & & 865 & \\
\hline & & $\Gamma 49$ & $37 / 6$ & $41 / 2$ & 37 & $42 / 7$ & $13 / 1$ & $170 / 18$ & & 871 & \\
\hline & & L50 & $37 / 6$ & $41 / 2$ & 37 & $42 / 7$ & $13 / 1$ & $170 / 18$ & & 871 & \\
\hline & & 51 & $31 / 4$ & $42 / 2$ & 37 & $26 / 3$ & $13 / 1$ & $149 / 12$ & & 853 & \\
\hline & & L52 & $29 / 4$ & $42 / 2$ & 37 & $32 / 6$ & $12 / 1$ & $152 / 15$ & & 856 & \\
\hline
\end{tabular}


bioRxiv preprint doi: https://doi.org/10.1101/2021.07.07.451566; this version posted July 9, 2021. The copyright holder for this preprint (which was not certified by peer review) is the author/funder, who has granted bioRxiv a license to display the preprint in perpetuity. It is

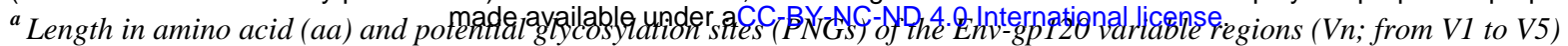
expressed as $V n / G$ ratio.

${ }^{b} \Sigma V n / G$ indicates the sum of the aa lengths of the $V n$ ( $n$; from 1 to 5) and the potential $G$ sites.

${ }^{c} M e a n / G$ indicates the mean length and $P N G$ value for each group of Envs.

${ }^{d}$ Gp160 shows the total length in aa of each Env including the gp41 subunit and the gp120 subunit.

${ }^{e}$ Mean gp160 length in aa for each group of Envs. 
A

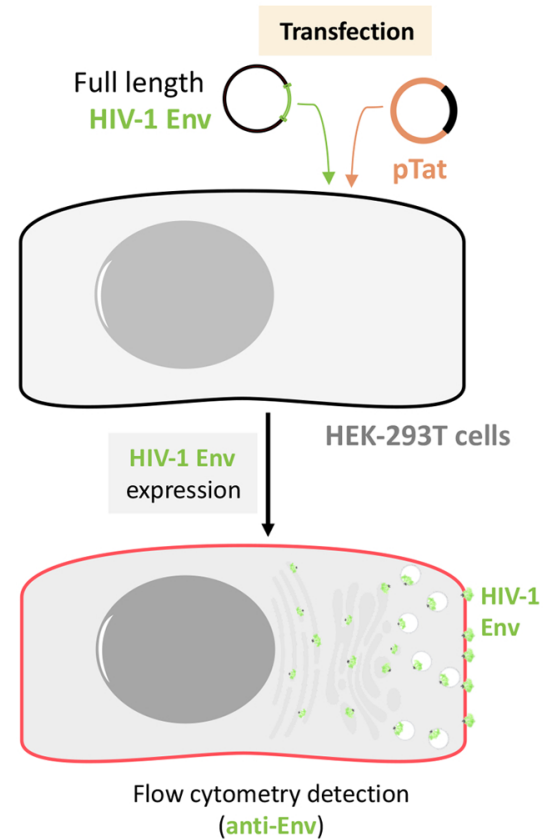

B

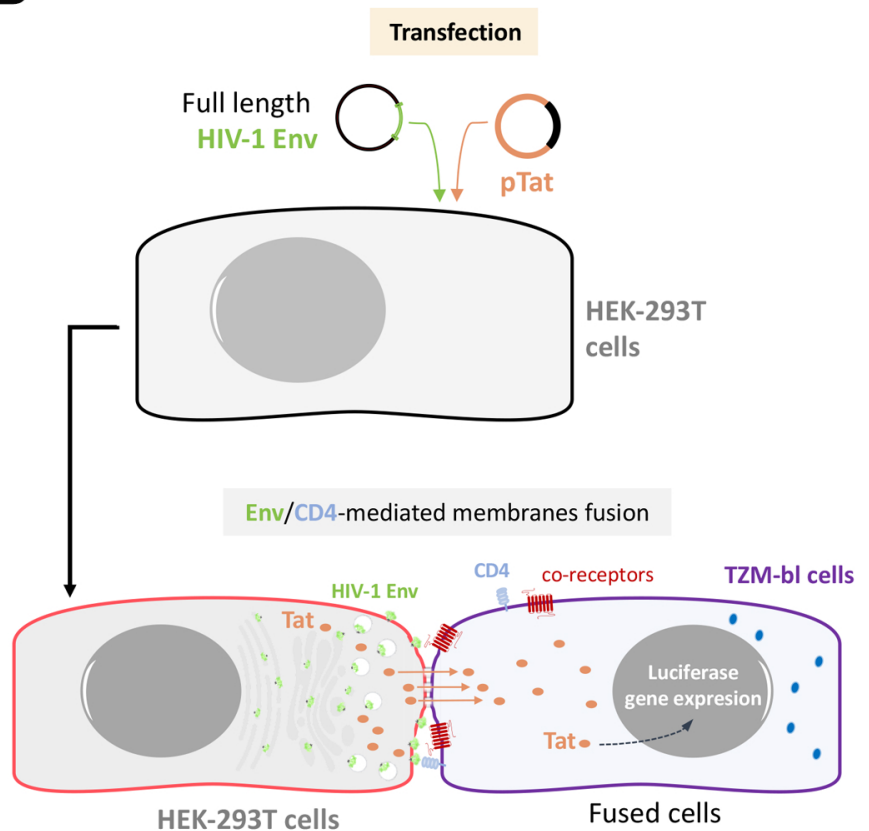

(Luciferase measurement)
C

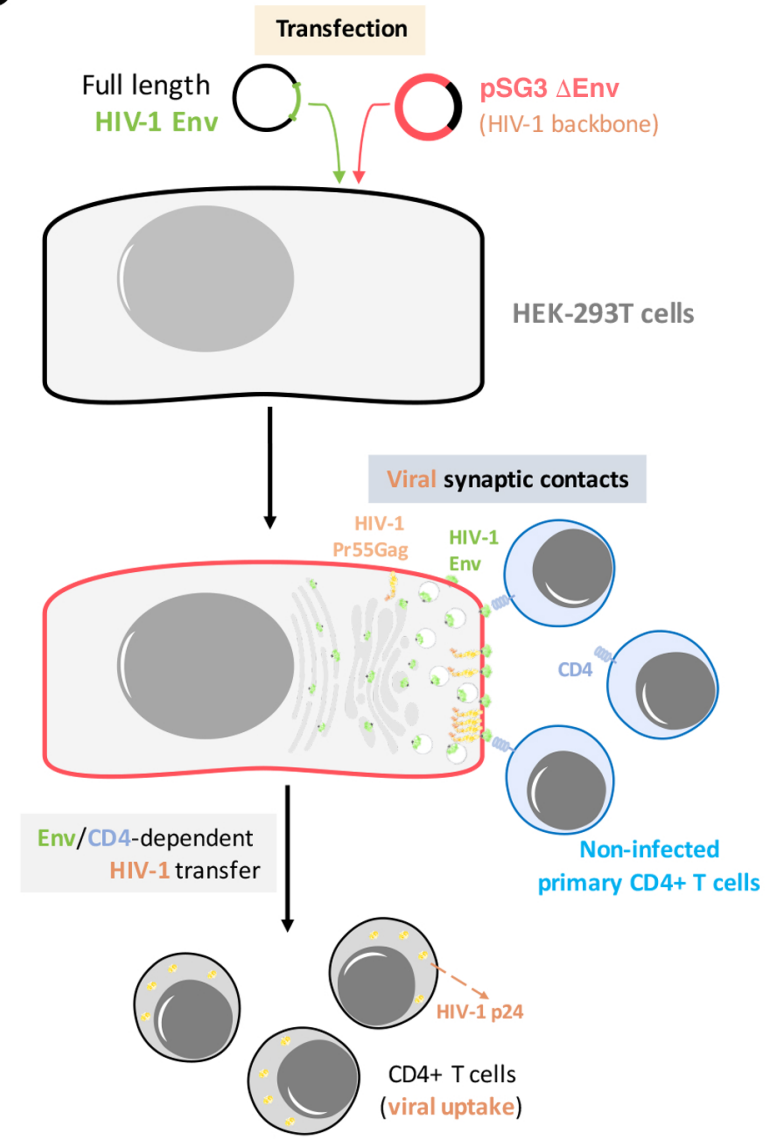

Flow cytometry detection (anti-p24)

D

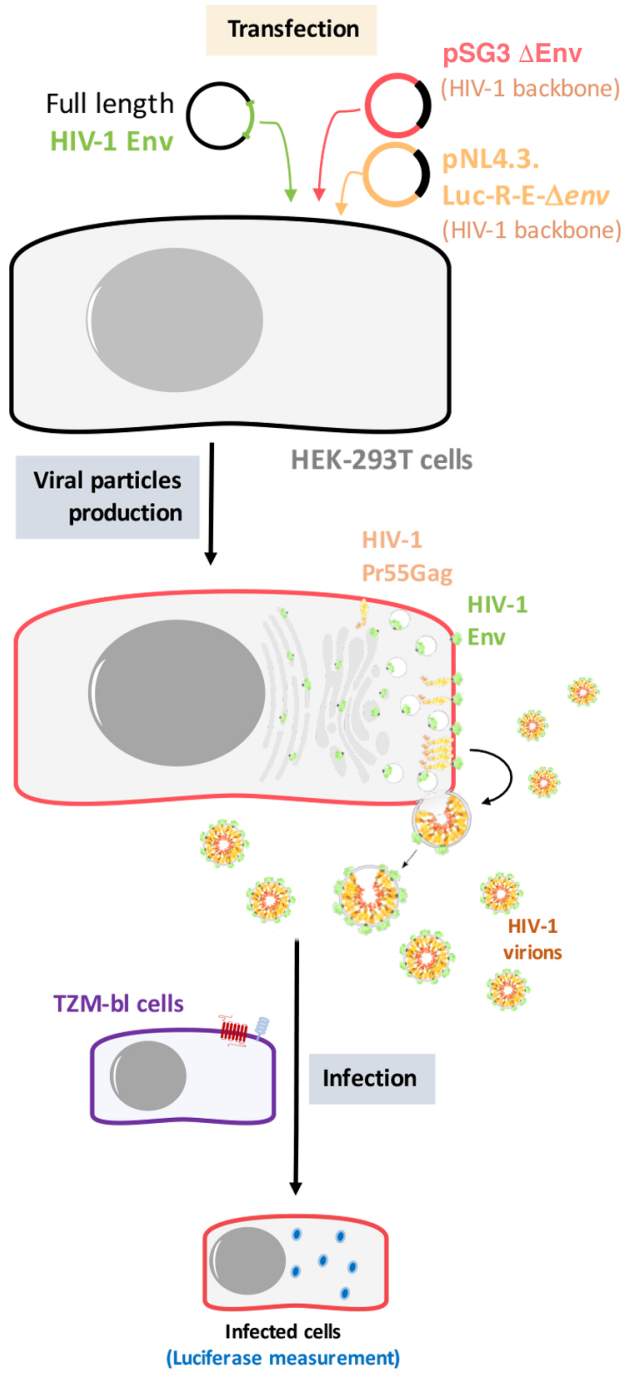

Figure 1

Silvia Pérez-Yanes et al. 


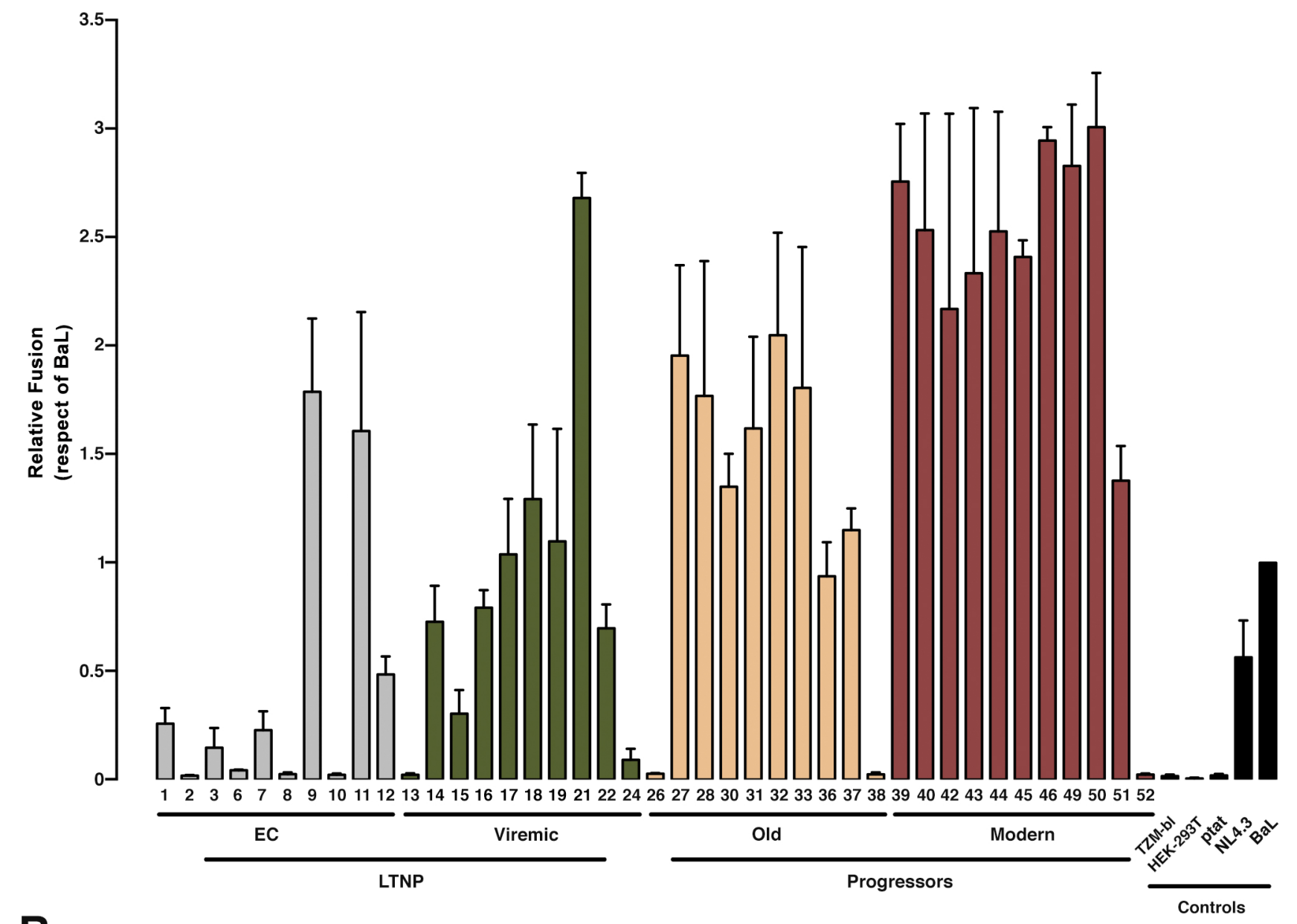

B

$p<0.0001$
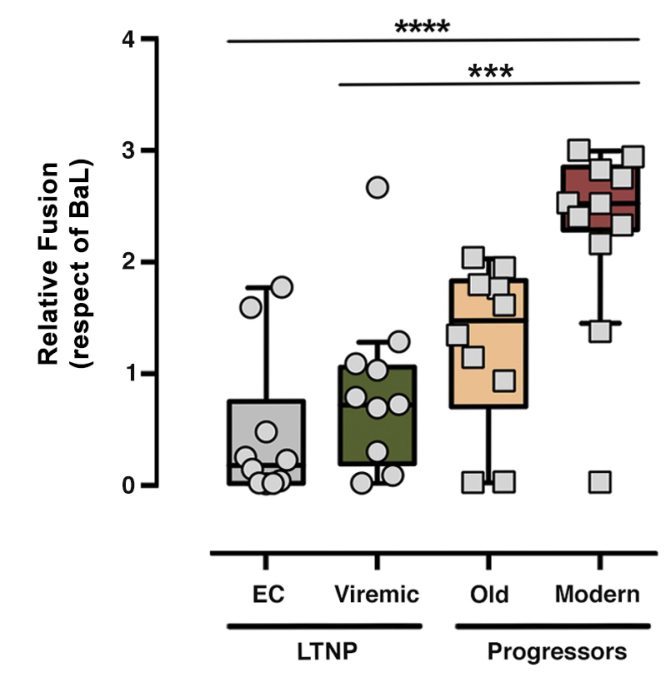

Figure 3 
A

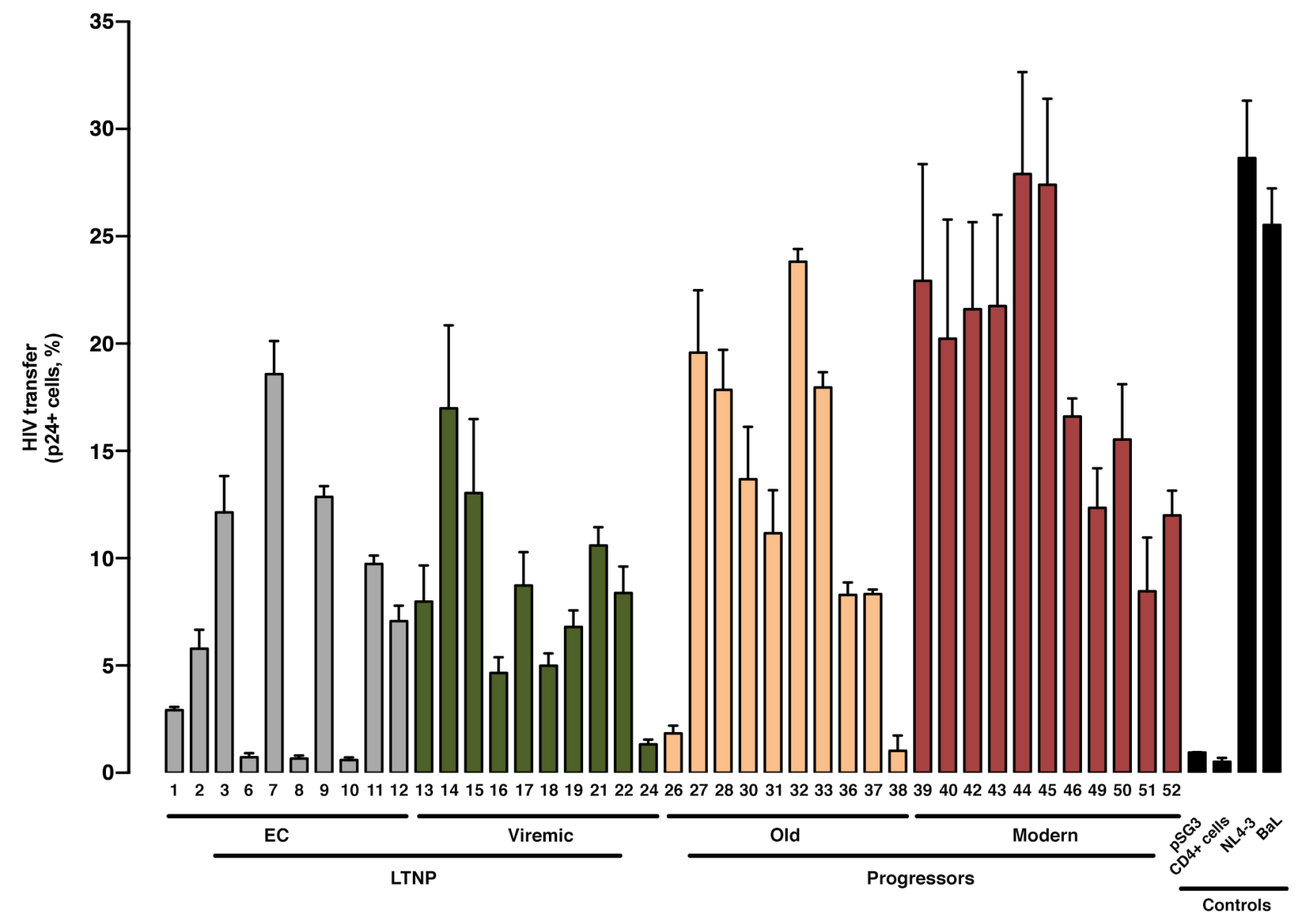

B

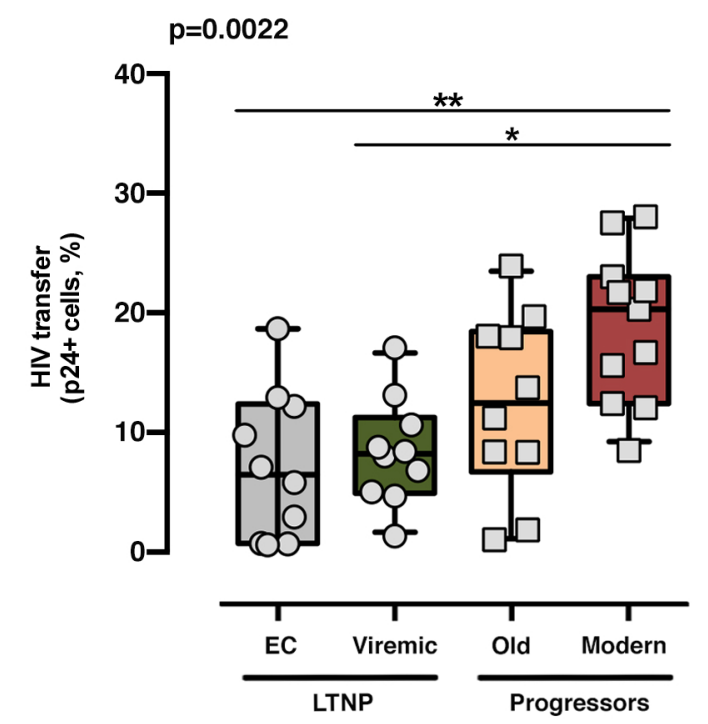


A

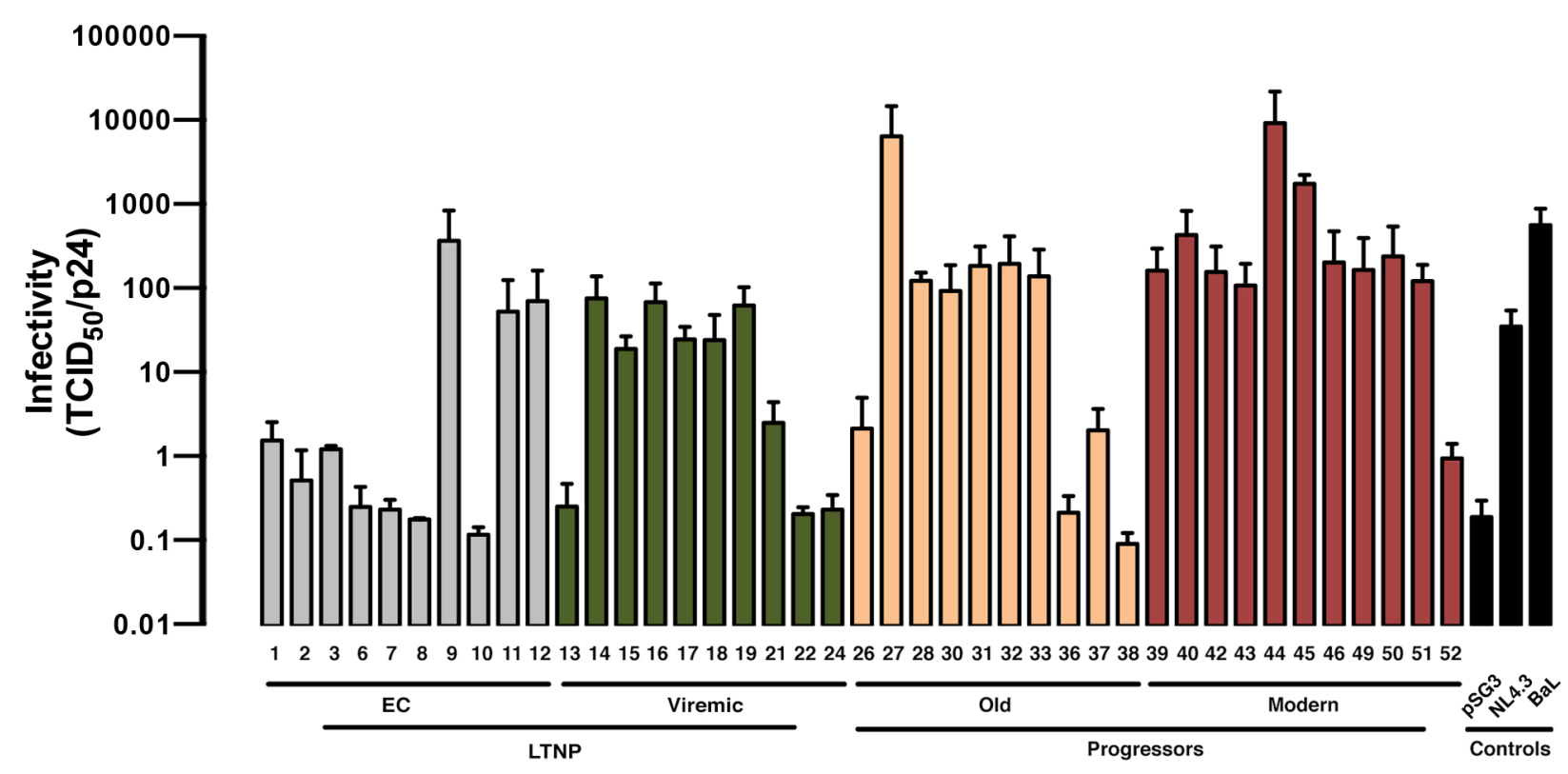

B

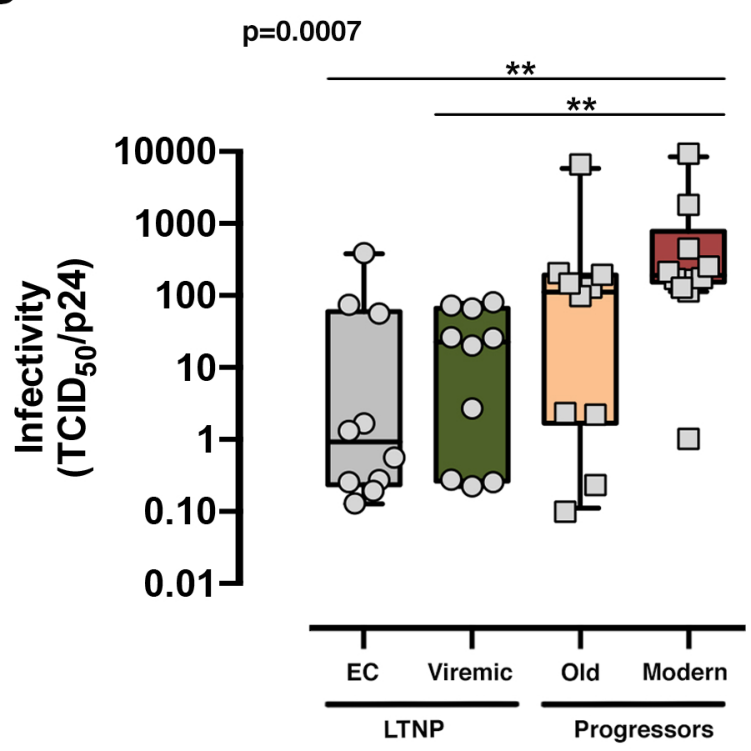


A

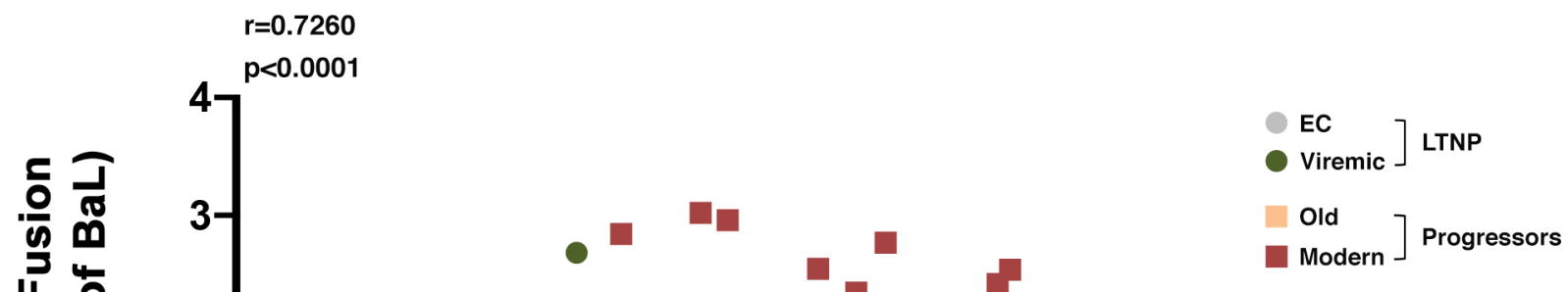

B

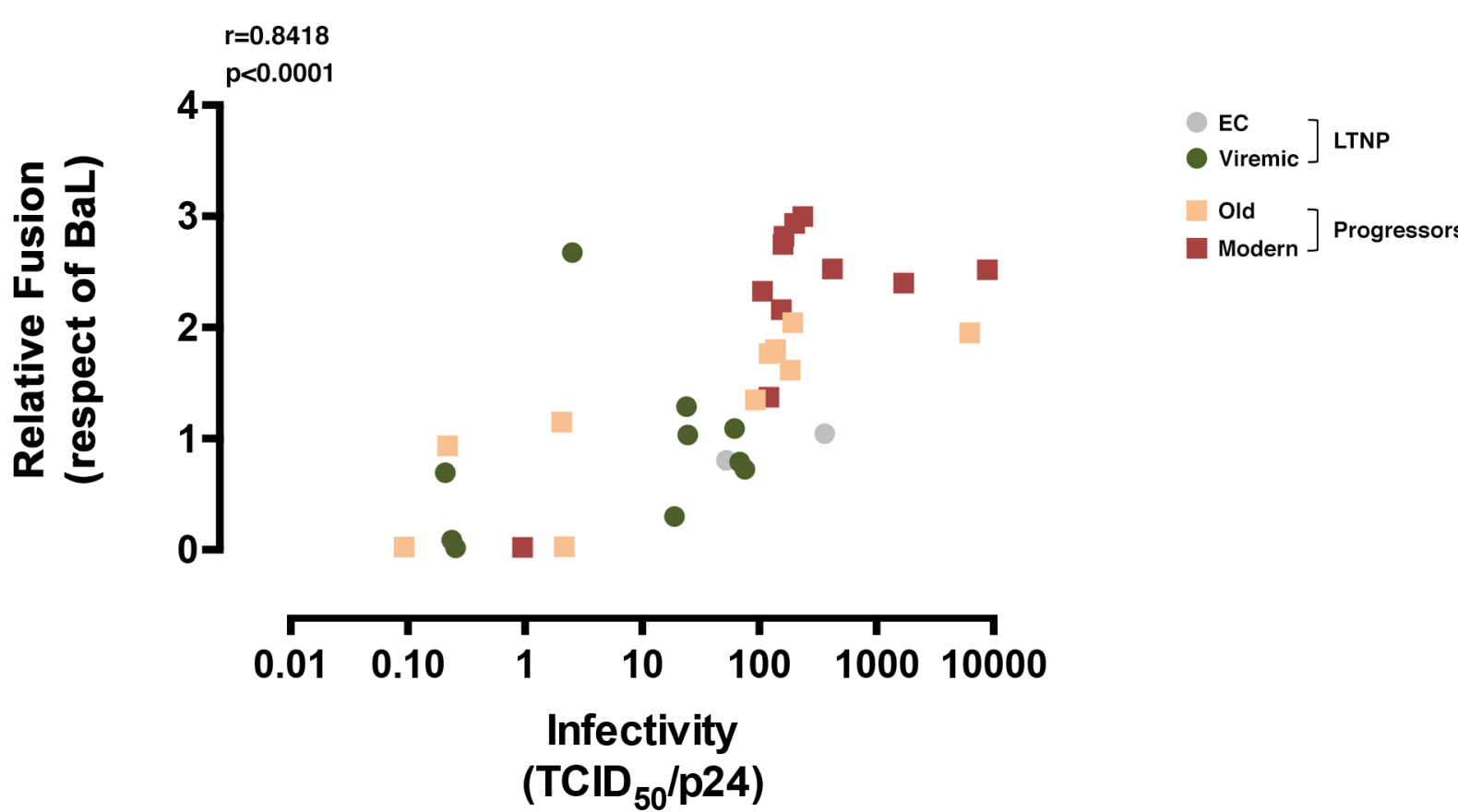

HIV Transfer

(p24+ cells, \%)

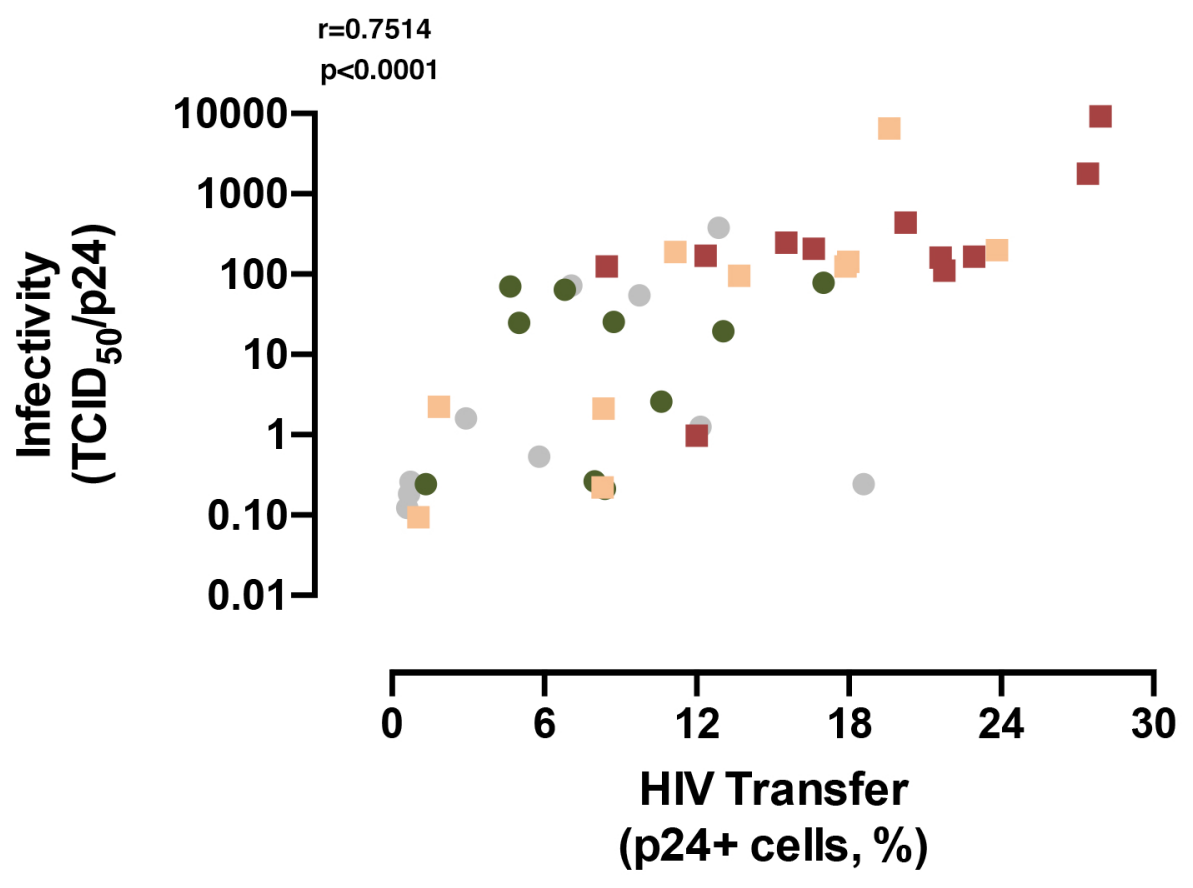


A

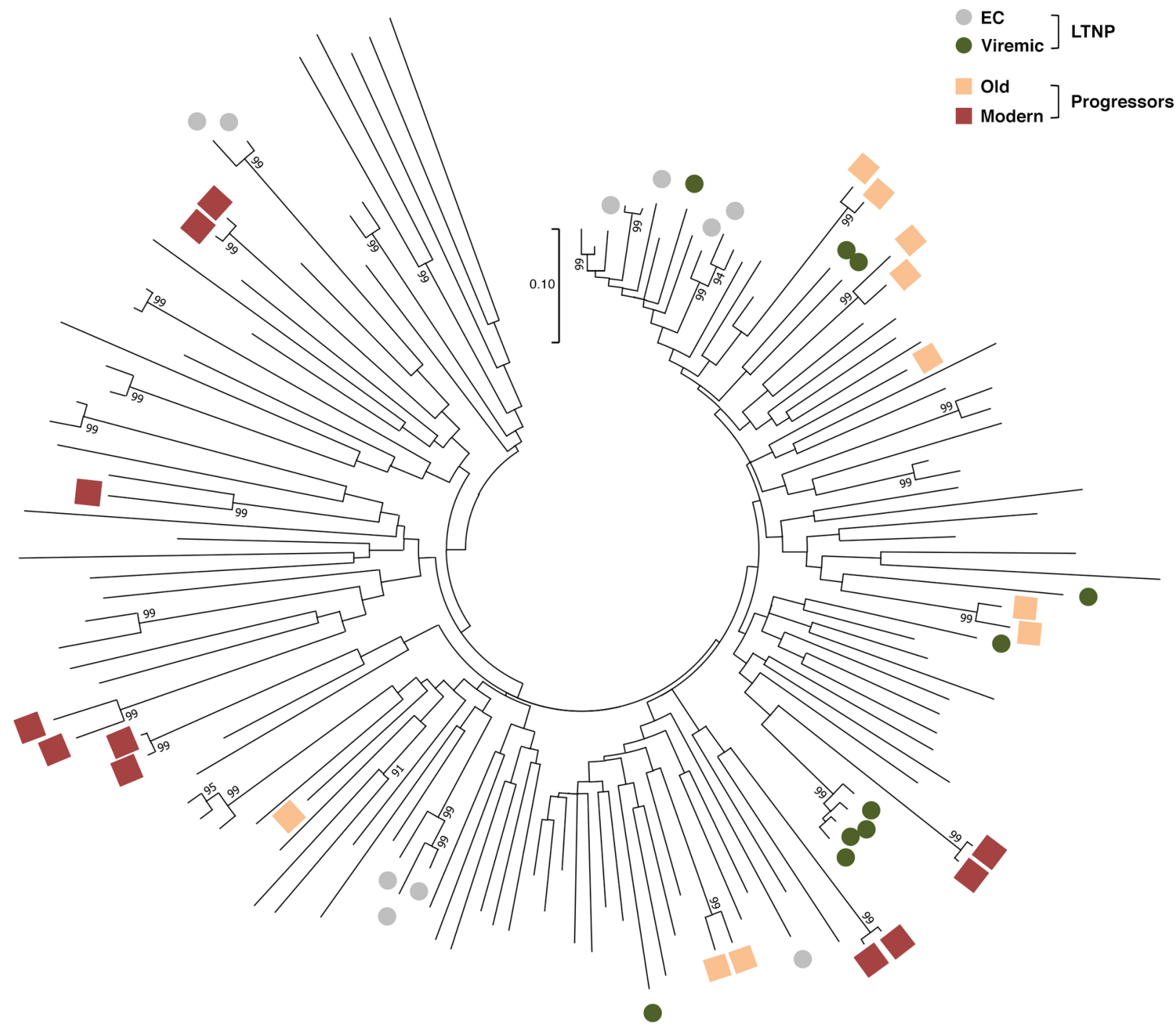


A
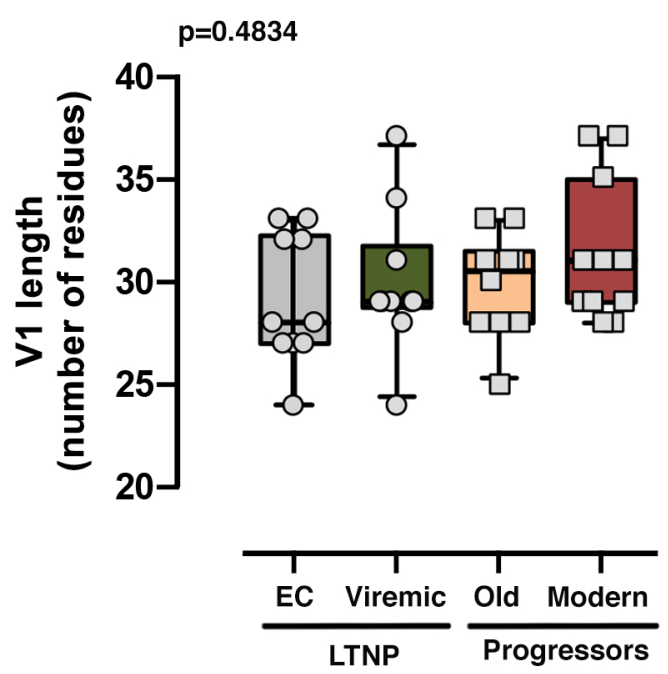

C
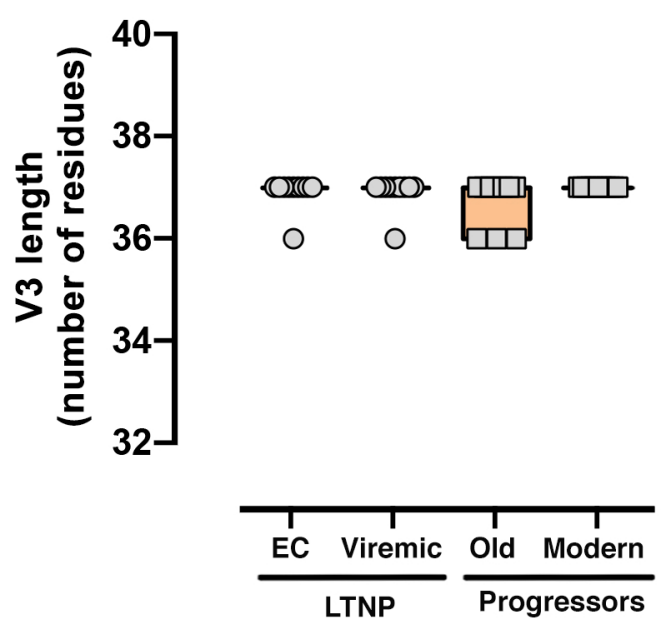

E

$p=0.0009$

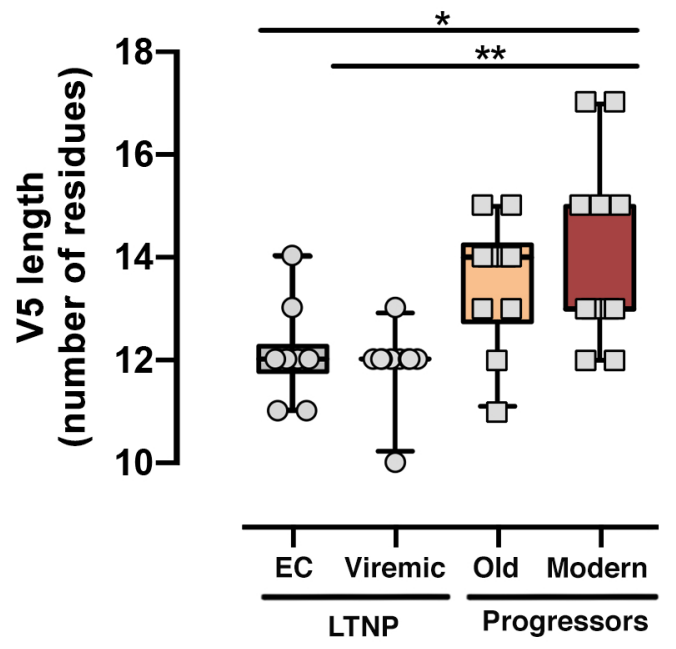

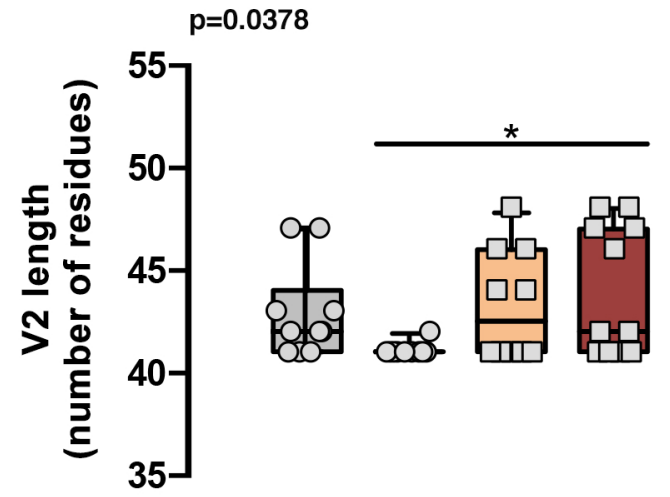

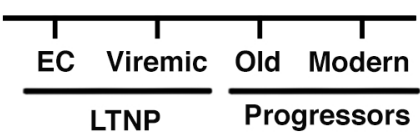

D

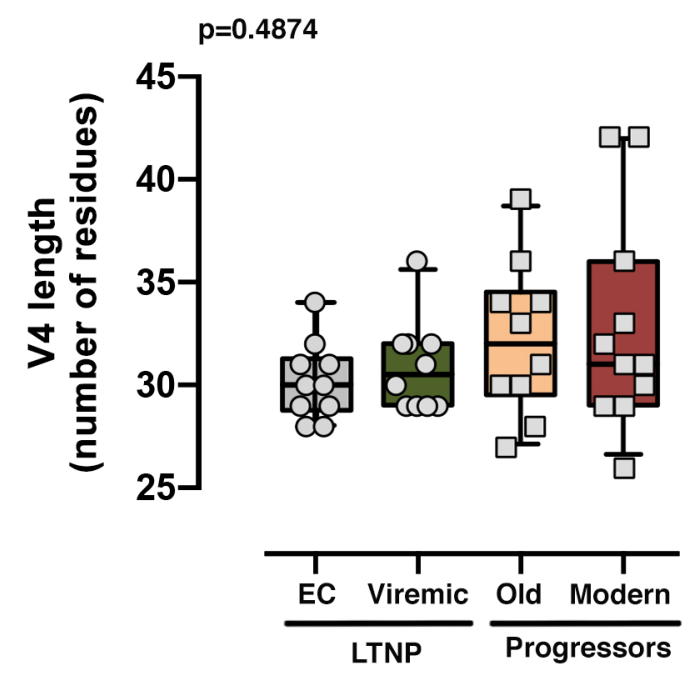

F $p=0.0214$

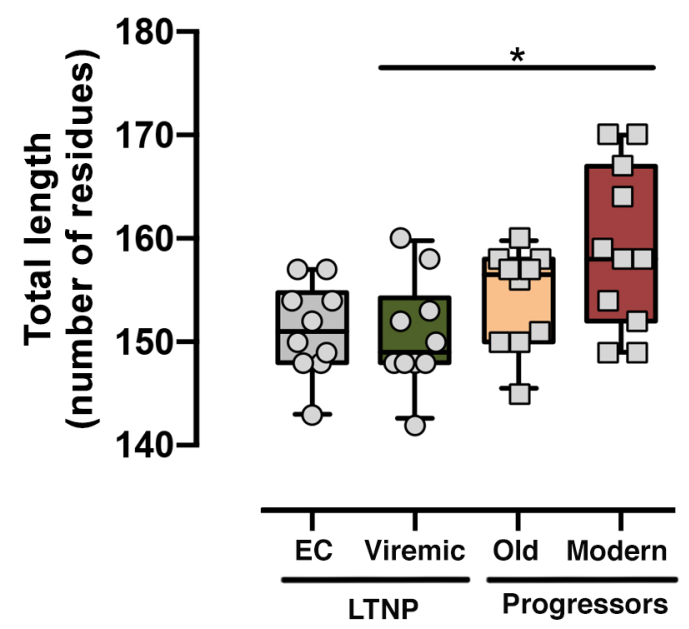


A

$\mathrm{p}=0.0001$

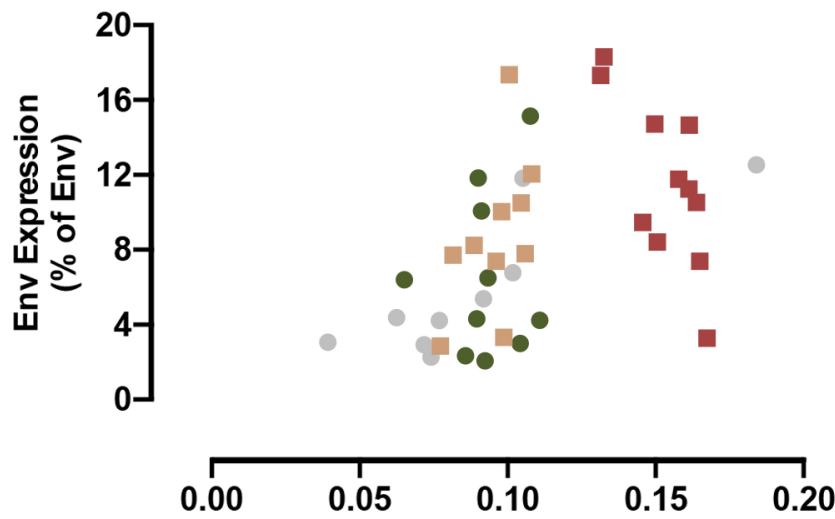

subB Ancestor Distance
Viremic ] LTNP

$\left[\begin{array}{l}\text { Old } \\ \text { Modern }\end{array}\right]$ Progressors

B

C

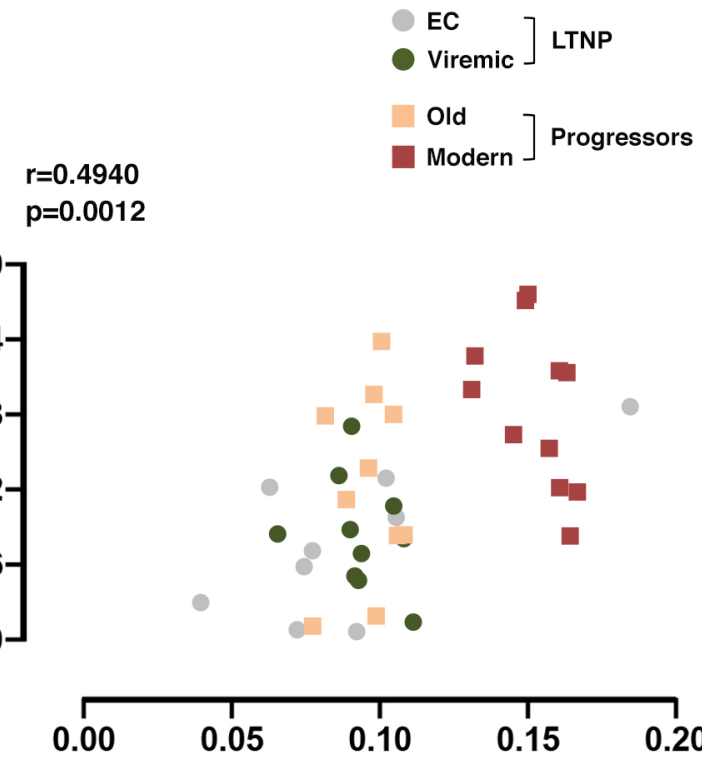

subB Ancestor Distance

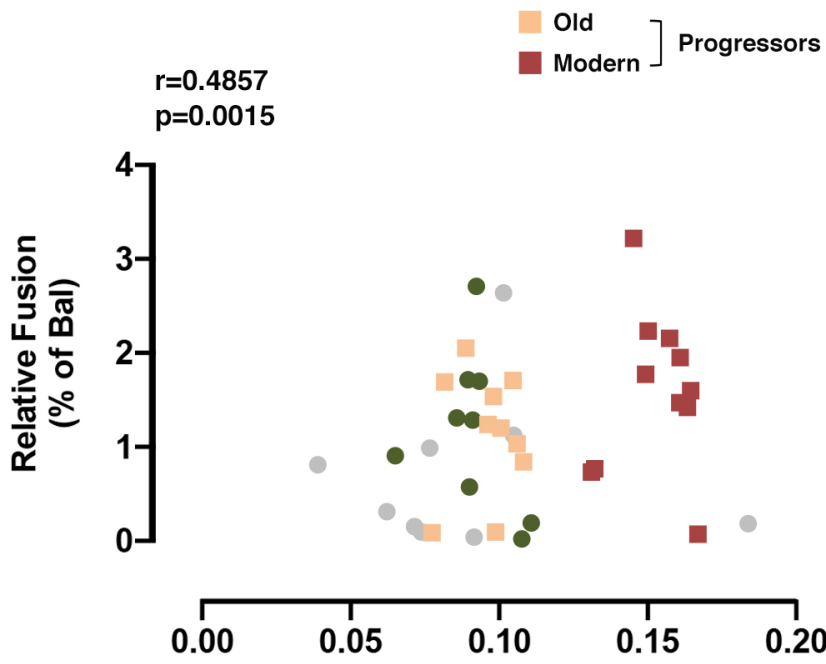

EC

subB Ancestor Distance

D

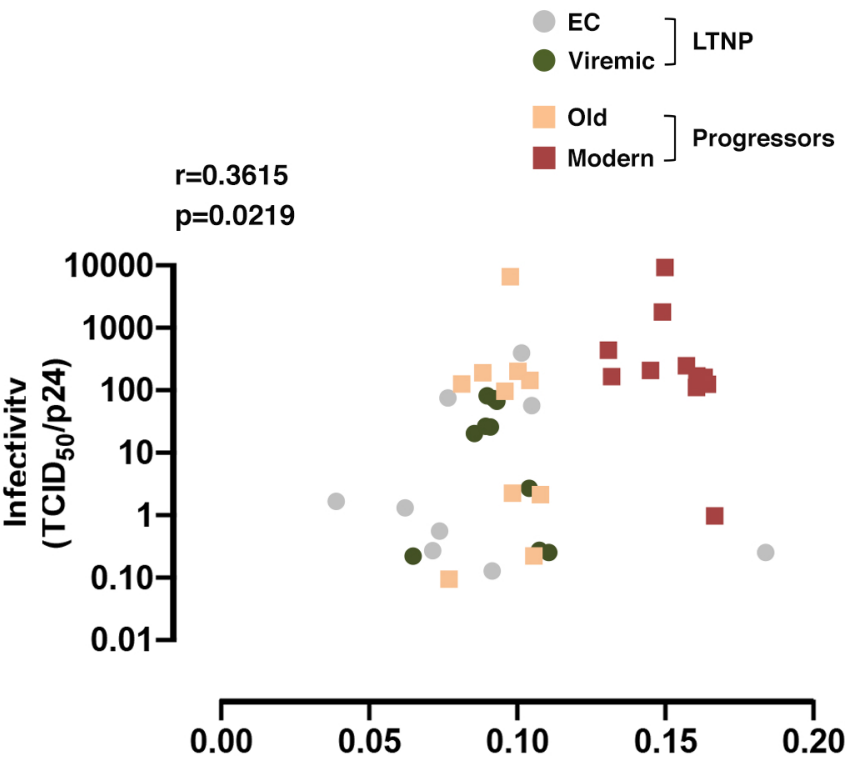

subB Ancestor Distance 